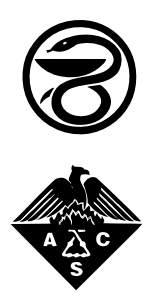

A publication of the

American

Pharmaceutical

Association

and the

American

Chemical

Society

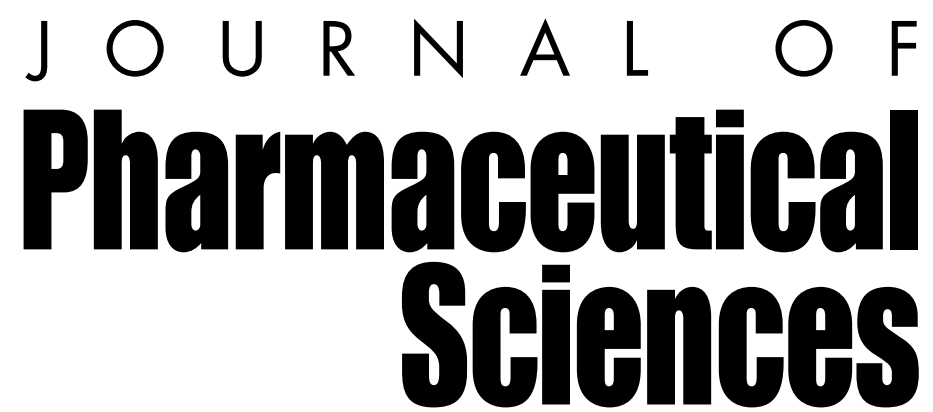

March 1997

Volume 86, Number 3

\title{
Physicochemical and Physiological Mechanisms for the Effects of Food on Drug Absorption: The Role of Lipids and pH
}

\author{
William N. Charman*x, Christopher J. H. Porter ${ }^{*}$, Sabena Mithani ${ }^{\dagger}$, and Jennifer B. Dressman ${ }^{\ddagger}$ \\ Received February 20, 1996, from the *Department of Pharmaceutics, Victorian College of Pharmacy, Monash University \\ (Parkville Campus), 381 Royal Parade, Parkville, Victoria 3052, Australia, the ${ }^{\dagger}$ College of Pharmacy, University of Michigan, \\ Ann Arbor, MI 48109, and the FInstitut fur Pharmazeutische Technologie, Johann Wolfgang Goethe-Universitat, \\ D-60439 Frankfurt am Main, Marie-Curie-Strase 9, Germany. Accepted for publication October 15, $1996^{\otimes}$.
}

\begin{abstract}
Drugs are absorbed after oral administration as a consequence of a complex array of interactions between the drug, its formulation, and the gastrointestinal (GI) tract. The presence of food within the Gl tract impacts significantly on transit profiles, $\mathrm{pH}$, and its solubilization capacity. Consequently, food would be expected to affect the absorption of co-administered drugs when their physicochemical properties are sensitive to these changes. The physicochemical basis by which ingested food/lipids induce changes in the Gl tract and influence drug absorption are reviewed. The process of lipid digestion is briefly reviewed and considered in the context of the absorption of poorly water-soluble drugs. The effect of food on Gl pH is reviewed in terms of location (stomach, upper and lower small intestine) and the temporal relationship between $\mathrm{pH}$ and drug absorption. Case studies are presented in which postprandial changes in bioavailability are rationalized in terms of the sensitivity of the physicochemical properties of the administered drug to the altered Gl environment.
\end{abstract}

\section{Introduction}

The presence of food within the gastrointestinal (GI) tract can markedly alter the oral bioavailability of drugs $\mathrm{s}^{1,2}$ via changes in the rate and/or extent of absorption, ${ }^{3-6}$ presystemic metabolism, 7,8 and systemic drug clearance. ${ }^{9-11}$ These changes can lead to variations in efficacy and toxicity profiles because medications are often taken under conditions of varying food and fluid intake. Although knowledge of such interactions is important from devel opmental, dinical, and regulatory standpoints, the effect of food on bioavailability has often been addressed in a largely phenomenological manner.

The presence of food within the GI tract was historically regarded as a barrier to absorption, leading to suggestions

\footnotetext{
${ }^{\otimes}$ Abstract published in Advance ACS Abstracts, J anuary 15, 1997.
}

that drugs should be taken on an empty stomach when possible.12,13 However, it is currently accepted that the interaction between food and drugs should be examined on an individual basis. ${ }^{14-16}$ The character and magnitude of the effect of food on bioavailability is a function of the drug, the dose, the nature of the formulation, the size and composition of the food, and the temporal relationship between food ingestion and drug administration. ${ }^{16}$

Notwithstanding the physical and chemical interactions that may occur between drugs and specific food components, $, 8,17,18$ altered postprandial absorption is generally a function of the changes associated with conversion from the fasted to the fed state. Changes due to (i) secretion of gastric acid and bile and pancreatic fluids, (ii) modification of gastric and intestinal motility patterns, and (iii) alterations in visceral blood and lymph flow have the most significant impact on absorption.

Algorithms for estimating drug absorption often involve consideration of the dose, aqueous solubility, and drug permeability. Amidon et al. ${ }^{19-21}$ developed useful predictive relationships for absorption in the fasted state employing physical model approaches for drugs with a "reasonable degree" of water solubility (considered in the context of the administered dose). However, the predictive aspects of postprandial bioavailability is more problematic.

The review of the literature presented here demonstrates that there is often a physicochemical basis to altered bi oavailability when drugs are administered postprandially. We briefly review the major physiological changes that occur in the postprandial GI environment to provide a framework for examining effects of food on bioavailability. We focus on the wide ranging effects of stimulation of the lipid digestion cascade (increased drug wetting and solubilization, recruitment of intestinal lymph, and effects on Gl motility) and modulation of $\mathrm{Gl} \mathrm{pH}$ (degree of ionization, solubility) on drug absorption. The effect of food on bioavailability from modifiedrelease formulations is not considered because we specifically 
address intrinsic absorption-related factors rather than extrinsic dose form effects.

\section{Lipids And The Post-Prandial Intestinal Environment}

Digestion and Absorption of Lipids-Lipids are a major constituent of food that can influence drug absorption. Ingested lipid decreases gastric motility, and the presence of lipid digestion products within the upper small intestine induces secretion of biliary and pancreatic fluids that dramatically alter the luminal environment. The digestion and absorption of lipids has received most attention in the nutritional and physiology literature because of the fundamental role it plays in health maintenance. ${ }^{22-26}$

Lipid digestion is the result of three sequential processes involving (i) dispersion of fat globules into a coarse emulsion of high surface area, (ii) enzymatic hydrolysis of the fatty acid glyceryl esters (primarily triglyceride lipid), and (iii) dispersion of the products of lipid digestion into an absorbable form. ${ }^{27}$ Lingual lipase secreted by the salivary gland and gastric lipase secreted by the gastric mucosa are responsible for initiating hydrolysis of ingested triglyceride (TG) to the corresponding diglyceride (DG) and fatty acid (FA) within the stomach. Liberation of these amphiphilic lipid digestion products, in combination with the shear produced by antral contraction and gastric emptying, facilitates formation of a crude emulsion that empties into the duodenum. The presence of lipid in the duodenum stimulates secretion of bile salts, biliary lipids, and pancreatic juice. Biliary lipids adsorb to the surface of the crude emulsion, stabilizing it and further reducing droplet size. ${ }^{27}$ Subsequently, the majority of TG hydrolysis occurs under the action of pancreatic lipase, which requires the presence of colipase to be active in the presence of bile salts. It is an interfacial enzyme that acts at the surface of the emulsified TG droplets to quantitatively produce the corresponding 2-monoglyceride (MG) and two FA.28,29 These digestion products are effective emulsifying agents, and because FA promotes binding of the lipase/colipase complex to the emulsion surface, ${ }^{30,31}$ the lipolytic process is essentially selfpromoting. Phospholipids are hydrolyzed to the corresponding lysophospholipids by phospholipase $A_{2}$ prior to absorption, and in quantitative terms, the majority of phospholipid reaches the GI tract via biliary secretion with only modest inputs from dietary sources.

In the early 1960s, Hofmann and Borgstrom ${ }^{32,33}$ subjected human postprandial intestinal contents to ultracentrifugationbased separation and determined that the in vivo products of lipid digestion partitioned between an oily phase and a solubilized bile salt mixed micellar phase. More recently, Carey et al. ${ }^{34,35}$ identified the presence of unilamellar vesicles in equilibrium with bile salt mixed micelles from aspirates of human postprandial intestinal fluid. Current understanding suggests that during lipolysis, digestion products "pinch off" from the surface of the TG/DG emulsion to produce liquid crystalline structures, which then form multilamellar and unilamellar structures in the presence of sufficient bile salt concentrations. Theintestinal mixed micellar phase described by Hofmann and Borgstrom is now thought to exist in a twophase equilibrium system with unilamel lar lipid vesicles. ${ }^{26,34,35}$

The absorptive membrane of the enterocyte is separated from the bulk aqueous phase of intestinal contents by a poorly mixed unstirred water layer (UWL) that constitutes a barrier to absorption of poorly water-soluble lipid digestion products. Although the specific absorption mechanisms have not been elucidated, the common role of the mixed micellar phase in solubilizing poorly water-soluble lipid digestion products and providing a concentration gradient for absorption of mono- meric lipids is generally accepted. ${ }^{36-38}$ Micelles are not absorbed intact, 39,40 and lipids are thought to be absorbed from a monomolecular intermicellar phase. ${ }^{37}$ In support of the importance of the intermicellar phase, concentrations of cholesterol several times higher than the saturated aqueous solubility can be achieved in the intermicellar environment. ${ }^{41,42}$ The dissociation of monomolecular lipid from the mixed micellar phase prior to absorption may be stimulated by a microclimate of lower $\mathrm{pH}$ associated with the absorptive site. ${ }^{43-45}$ Reports have described the existence of an enterocyte-based carrier system, termed the microvillus membrane fatty acid binding protein, which in tandem with passive diffusion may be responsible for the uptake of $F A$ and other lipid substrates into the enterocyte. ${ }^{46,47}$ Although evidence is mounting to suggest that uptake of lipid digestion products may not be entirely via simple diffusion, further work is required to clearly define the factors and processes involved.

The majority of absorbed long-chain FA and MG migrates to the endoplasmic reticulum where re-esterification and assembly into lipoproteins occurs prior to secretion into lymph. ${ }^{48}$ As a general guide, FA of chain length $<12$ carbons ( $10 \%$ of dietary lipid) are absorbed via the portal blood, ${ }^{49}$ whereas FA with longer chain lengths are reesterified and transported via intestinal lymph. However, the chain length dependence of portal or lymphatic transport is less clear cut than this "rule of thumb" as there are reports of Iymphatic transport of medium-chain FA and portal blood absorption of long-chain FA. 50,51

Bile and Bile Salt Micelles-An average composition of human gall bladder bile is $84 \%$ water, $11.5 \%$ bile salts, $3 \%$ lecithin, $0.5 \%$ cholesterol, and $1 \%$ other components, such as bile pigments, inorganic ions, and protein. ${ }^{52}$ In response to the intestinal presence of digestion products (especially lipid digestion products), cholecystokinin-mediated contraction of the gall bladder and relaxation of the sphincter of Oddi leads to expulsion of bile, with peak flow occurring $\sim 30 \mathrm{~min}$ after meal ingestion. Although variable, typical bile salt concentrations in the fasted intestine are 4-6 mM compared with postprandial levels of $10-20 \mathrm{mM} .{ }^{53}$ Approximately $40 \%$ of bile salts are conjugates of cholic acid, $40 \%$ are conjugates of chenodeoxycholic acid, and the remaining $20 \%$ are conjugates of deoxycholic acid. 53,54

Bile salts form polymolecular aggregates, the structural characteristics of which are dependent on solution $\mathrm{pH}$, temperature, compositional distribution of other bile acids, and the presence of biliary lipids and lipid digestion products. ${ }^{55}$ Although the formation of bile salt aggregates is termed micellization, bile salt aggregation is more gradual than observed for synthetic surfactants, and the aggregation number is much less. Carey and Small ${ }^{56}$ described bile salts forming either primary or secondary micelles. Primary bile salt micelles have aggregation numbers up to 10 and are formed via hydrophobic interactions, whereas secondary micelles are formed via hydrogen bonding interactions of the primary micellar structures.

The chemistry of mixed bile salt micelles is dictated by the structural inclusion of lecithin, lysolecithin, and the products of lipid digestion that decreases the critical micelle concentration (cmc), increases the size of the micelle, and significantly increases solubilization capacity. For example, the inclusion of swelling amphiphiles such as lecithin and MG decreases the $\mathrm{cmc}$ of mixed micellar systems to values $<1 \mathrm{mM} .{ }^{56-59}$ Therefore, it is likely that the cmc of mixed bile salt micelles is surpassed even in the fasted state. The secretion of bile in response to food is responsible for an overall increase in the solubilizing capacity of the Gl tract by increasing micelle numbers rather than increasing bile salt levels to supramicellar concentrations. 


\section{The Role of Bile in Drug Dissolution and Solubilization}

The presence of bile may improve the bioavailability of poorly water soluble drugs by enhancing the rate of dissolution and/or solubility. An increase in the rate of dissolution can occur via (i) a decrease in the interfacial energy barrier between solid drug and the dissolution medium (via enhanced wetting), leading to an effective increase in surface area, or (ii) an increase in solubility via micellar solubilization. However, a consequence of drug solubilization within the bile salt micelle is a decrease in the apparent diffusion coefficient of the drug. In general, enhanced wetting predominates at bile salt concentrations below the $\mathrm{cmc}$, whereas enhanced solubility is dominant at concentrations above the $\mathrm{cmc}^{60}$ It is important to note that changes in the dissolution rate of poorly water-soluble drugs due to wetting or solubilization is compound dependent due to the specificity of the interactions associated with these processes. $56,58,59$

Poorly water-soluble drugs partition between the postprandial multilamellar and unilamellar structures, emulsion droplets, and the mixed micellar phase. The character of these colloidal phases is controlled by the relative concentrations of bile salts, biliary lipids, and lipid digestion products and is therefore continually changing. As time progresses after ingestion of a meal and the relative proportions of the high lipid load emulsion droplets and multilamellar vesicles decreases relative to the end stage mixed micelle and unilamellar vesicles, the nature of the available "dissolution media" changes correspondingly. Therefore, dissolution is subject to change not only as a function of the fed/fasted cycle but also the kinetics of lipid digestion.

Solubility and Wetting-The effect of bile salt solubilization has been studied for many drugs; for example, griseofulvin, ${ }^{61-63}$ danazol , ${ }^{58}$ digoxin, ${ }^{64}$ diethylstil bestrol, ${ }^{65} \mathrm{di}-$ azepam, ${ }^{66}$ hal ofantrine, ${ }^{67}$ leucotriene antagonists, ${ }^{68}$ and gemfibrozil.69 Typically, solubility may increase $0.2-2$ orders of magnitude in representative postprandial simple micellar systems compared with buffer control. The further addition of lecithin and/or lipid digestion products to simple bile salt micelles does not necessarily lead to further increases in solubility or dissolution rate.

Bile salts can increase the rate of dissolution via enhanced wetting in a compound-specific manner. For example, Miyaza$\mathrm{ki}$ et al. ${ }^{71,72}$ suggested that the enhanced dissolution of phenyl butazone in simple bile salt solutions was mediated via increased wetting, whereas micellar solubilization was responsible for improved dissolution of indomethacin. Bakatselou et al. ${ }^{58}$ investigated the powder dissolution rate of five steroids in sodium taurocholate (NaTC) solutions representative of fasted and fed states (3.75 and $15 \mathrm{mM} \mathrm{NaTC}$, respectively). The increased dissolution under simulated fed state conditions for four of the five steroids ( $\log P$ values 1.011.94; viz., triamcinolone, hydrocortisone, dexamethasone, and betamethasone) was primarily augmented by improved wetting. In contrast, the increased dissolution of danazol (log P 4.5) was primarily mediated via solubilization. Subsequent studies examined the dissolution of hydrocortisone in simple and mixed micellar systems and determined that wetting was the predominant factor that improved the rate of dissolution in simple bile salt micelles, whereas solubilization appeared to be major mechanism for improving dissolution in the mixed micellar systems. ${ }^{59}$ The solubility and dissolution of cholesterol in bile salts has been extensively studied by Higuchi et al. ${ }^{73-80}$ Although these studies were targeted towards understanding gallstone dissolution, they provide valuable data regarding the dissolution of highly lipophilic compounds. Dissolution was facilitated by simple bile salt micelles, although addition of lecithin to form mixed micelles markedly decreased dissolution in spite of improved solubility. Subsequent studies demonstrated that dissolution in mixed micelles was not diffusion controlled but limited by an electrostatic barrier at the dissolving interface. ${ }^{77,80}$ Although cholesterol is an extreme example, surface-based reactions may become important for extremely lipophilic compounds with minimal aqueous solubility.

Not all interactions of poorly water-soluble drugs with bile salts lead to increased solubilization. Examples where the formation of insoluble, poorly absorbed drug-bile salt complexes leads to decreased bioavailability include, among others, pafenolol, 81 tubocurarine, ${ }^{82}$ neomycin and kanamycin, ${ }^{83}$ and various large molecular weight antibiotics. ${ }^{84}$ Related situations where poorly absorbed complexes are formed between the drug and components of the ingested meal include the well-known examples of tetracyline ${ }^{85}$ and penicillamine. ${ }^{86}$ These examples of food-affected bi oavailability are outside the scope of this review and reviews by Welling ${ }^{15,16}$ should be consulted for further detail.

The lack of predictability of solubility and dissolution rate of poorly water-soluble drugs in bile salt systems indicates the compound-specific nature of the interaction. Additionally, there is a likely differential between the sensitivity of the kinetic processes (rate of wetting and rate of dissolution) and the equilibrium processes (solubility and composition of the drug containing micelle) in the micellar components. Figure 1 is a schematic representation that summarises the various steps involved in lipid digestion, the formation of the various micellar phases, and the influence that the postprandial Gl environment can have on the dissolution and solubilization of coadministered drugs.

\section{Absorption, Permeability, and the Postprandial Intestine}

The constituents of the mixed micellar phase impact on the intestinal permeability of poorly water-soluble drugs via three major processes. First, lipid digestion products and bile salts characteristic of the fed state may alter the intrinsic permeability of the intestinal membrane leading to increased penetration via paracellular or transcellular routes. Second, solubilization of poorly water-soluble drugs within bile salt micelles may facilitate diffusion through the UWL leading to increased absorption. Third, and conversely, solubilization may decrease the intermicellar "free" fraction of drug that could lead to a decrease in absorption. These divergent effects are the basis for the often contradictory reports concerning drug absorption when drugs are administered as solubilized systems. These issues are not new, and the points raised in a 1970 review by Gibaldi and Feldman ${ }^{87}$ are as relevant today as when the article first appeared.

The permeability enhancing abilities of bile salts, FA, and MG in the intestinal tract is well known. ${ }^{88-93}$ When considering these naturally occurring permeability enhancers, it is apparent that the intestinal mucosa is frequently subjected to dietary-induced damage and that mechanisms have evolved for rapid repair. ${ }^{94}$ Kvietys et al. ${ }^{95}$ studied the role of lipolytic digestion products in causing mucosal injury and demonstrated that perfusion of emulsified oleic acid through the rat small intestine induced damage to villus tips, although the damage was rapidly repaired within $1 \mathrm{~h}$ of stopping the perfusion. These data led to the conclusion that damage to the intestinal epithelium by the products of lipid digestion may be a common occurrence during the normal digestive and absorptive processes.

The following representative examples describe the range of effects that lipid digestion products and bile salts may have on drug absorption when studied using in situ methods. 


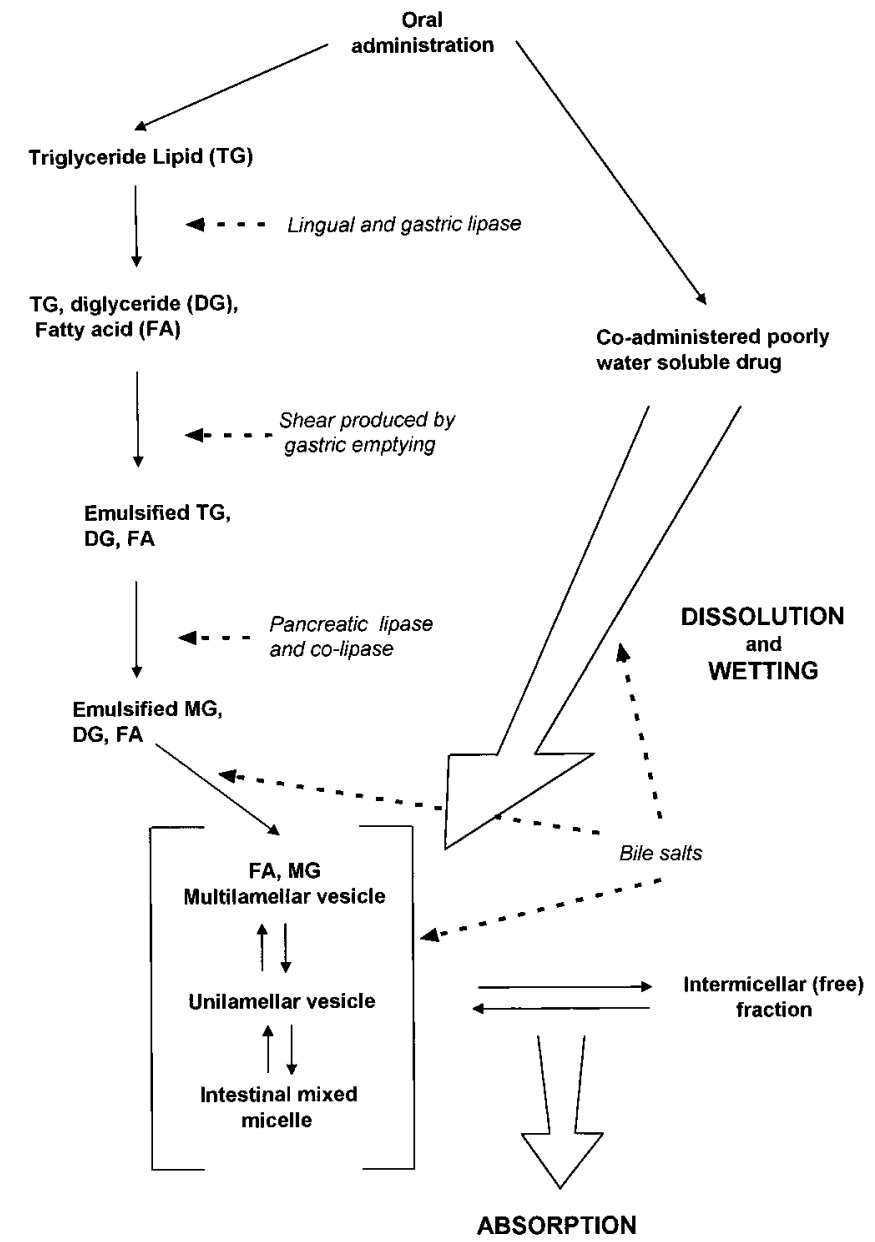

Figure 1-Schematic representation of the processing involved with the digestion of lipids, the formation of the various colloidal phases present within the postprandial intestine, and the subsequent absorption of the lipid digestion products (and drugs) by the enterocyte. Poorly water-soluble drugs that are coadministered with either food or lipid-based formulations can benefit from the processes involved with lipid digestion through enhanced wetting and solubilization facilitated by the conditions present in the postprandial intestine. Absorption is generally passive in nature, with the drug and lipid digestion products absorbed from the intermicellar phase.

However, caution must be exercised when extrapolating data from in situ absorption/perfusion studies to intact animals where the physiological and compositional characteristics of the Gl tract are constantly changing. The effect of bile salts on the intestinal absorption of model hydrophilic (paracetamol and theophylline) and lipophilic drugs (griseofulvin, ketaconazole, and dantrolene) was studied by Poelma et al.96,97 using a rat in situ intestinal perfusion technique. Simple or mixed bile salt micelles had no effect on absorption of the hydrophilic drugs, leading to the conclusion that bile salt micelles had minimal effect on the intrinsic barrier function of either the UWL or the intestinal membrane. In contrast, simple or mixed bile salt micelles reduced the absorption of the lipophilic drugs, which in the case of griseofulvin was correlated with a reduction in the free fraction of drug due to solubilization. Similar profiles have been reported by SeguraBono et al. ${ }^{98}$ who, in the latest of a series of reports, $99-102$ described a decrease in the rate of absorption of a range of phenylalkylcarboxylic acids solubilized in simple or mixed micelles.

In contrast to the data just presented, where solubilization decreased absorption, numerous reports have described enhanced intestinal absorption from bile salt-solubilized systems. For example, O'Reilly et al. ${ }^{103,104}$ described enhanced absorption of a highly lipophilic rimnophenazine derivative in the presence of high concentration simple or mixed bile salt micelles. The tacit assumption when the absorption of lipophilic compounds is improved with bile salt micelles is that transcellular absorption is enhanced. In this study, the absorption of a poorly absorbed hydrophilic marker (PEG 4000) $)^{105}$ was simultaneously assessed. At bile salt concentrations $>40 \mathrm{mM}$, there was a significant increase in the permeability of PEG 4000, whereas concentrations of $80 \mathrm{mM}$ were required to enhance absorption of the lipophilic rimnophenazine derivative. This difference suggested that the enhanced permeability of PEG 4000 was due to a change in the paracellular permeability of the membrane mediated by the bile salt solutions. Similar observations were made with streptomycin and gentomycin for which mixed micellar systems markedly enhanced absorption. ${ }^{106}$ Subsequent studies demonstrated that the enhanced absorption was due to an alteration of the membrane permeability by the lipid component of the micelles, 107,108 with the high aqueous solubility of streptomycin and gentomycin most likely favoring the paracellular route of absorption.

In summary, solubilization in the terminal phases of lipid digestion, notably the intestinal micellar phases, can have a considerable effect on the absorption of poorly water-soluble drugs. Consequently, the potentially large increase in dissolution and solubilization of such compounds in the postprandial environment is the most likely basis for enhanced absorption.

\section{Altered GI Transit Profiles}

The products of lipid digestion delay gastric emptying, 109,110 and most pharmaceutical attention has focussed on the relationship between gastric emptying, food ingestion, and the handling of different dosage forms. ${ }^{111-115}$ Generally, delayed gastric emptying has the potential to increase absorption of poorly water-soluble drugs by increasing the time available for dissolution. For acid-labile and ionizable drugs, coadministration with food increases the residence time in the acidic environment, which impacts on solubility and stability issues. However, the increase in stomach $\mathrm{pH}$ in response to food ingestion makes it difficult to predict the likely overall effect on bioavailability, and these issues are addressed in a subsequent section.

\section{Intestinal Lymphatic Drug Transport}

The intestinal lymphatics are a specialized transport path for highly lipophilic drugs, lipids, and lipidic derivatives. The physiological, biopharmaceutic, and formulation-related factors that influence lymphatic drug transport have been recently reviewed. ${ }^{116-119}$ Once a drug has gained access to the intestinal lymphatics (in association with intestinal lipoproteins), it drains into the thoracic lymph duct that empties into the systemic circulation at the junction of the left internal jugular and left subclavian veins. Therefore, Iymphatic transport can bypass hepatic first-pass metabolism and thereby increase bioavailability, and target drugs to regions of the body directly supplied by the mesenteric lymphatics.

Examples of compounds that are transported (to varying degrees) by the intestinal lymphatics include cyclosporin, 120 naftifine, ${ }^{121}$ probucol,122 mepitiostane, ${ }^{123-124}$ lipophilic vitamins and vitamin derivatives, ${ }^{125}$ hal ofantrine, ${ }^{126}$ xenobiotics such as DDT and related analogs, ${ }^{127-129}$ benzo-(a)-pyrene, ${ }^{130}$ and numerous lipophilic prodrugs. ${ }^{118}$

Compounds transported via the intestinal lymphatics are generally associated with the lipid TG core of chylomicrons that are formed by the enterocyte. The resynthesis of TG to 
Table 1-Examples of Increased Postprandial Oral Bioavailability and the Likely Basis for the Increased Absorption

\begin{tabular}{cccc}
\hline Compound & Increase in Bioavailability & Basis for Food Effect & Ref \\
\hline Griseofulvin & $3-5$-fold (humans) & $\uparrow$ solubilization $\rightarrow$ portal blood transport & $62,63,135$ \\
Danazol & 4 -fold (humans) & $\uparrow$ solubilization $\rightarrow$ portal blood transport & 58,137 \\
$\alpha-$-Tocopheryl & 5 -fold (dogs) & $\uparrow$ solubilization $\rightarrow$ portal blood and lymph & transport \\
nicotinate & 28 -fold (humans) & $\uparrow$ solubilization $\rightarrow$ portal blood transport & 132,140 \\
Halofantrine & 10 -fold (dogs) & possible lymph transport & 67,143 \\
& 3 -fold (humans) & $\uparrow$ solubilization $\rightarrow$ portal blood transport & 145 \\
Atovaquone & $3-5$-fold (humans) & likely $\uparrow$ solubilization $\rightarrow$ portal blood transport & \\
Retinoic acid & $2-5$-fold (humans) & possible lymph transport & 147,148 \\
derivatives & & &
\end{tabular}

support chylomicron formation occurs via either of two pathways, with the major and most energy-efficient path being the direct and sequential acetylation of absorbed 2-MG with activated FA to form the corresponding DG and TG lipids. The resynthesized TG is then progressively shunted through intracellular organelles where the surface is stabilized by addition of phospholipids and apoproteins. The obligatory dependence of chylomicron formation on the phospholipid and apoprotein coating, and their ordered and sequential assembly, have been the subject of various reviews. ${ }^{22,23,26}$ Phospholipids, which cover as much as $80 \%$ of the chylomicron surface, ${ }^{131}$ are formed in the enterocyte via reesterification of absorbed Iysophospholipids with an activated long-chain FA.

The rate of fluid transport in the intestinal lymphatics is $\sim 0.2 \%(\mathrm{v} / \mathrm{v})$ compared with portal blood. ${ }^{132}$ Consequently, there is minimal opportunity for the selective Iymphatic transport of small molecular weight, water-soluble drugs where absorption via the portal blood or lymph is largely governed by the relative rates of fluid flow. However, association of lipophilic drugs with the TG core of chylomicrons can provide a means for attaining high lymphatic drug concentrations and thereby contribute to bioavailability.

The major factors for Iymphatic transport to be a significant contributor to bioavailability include coadministration of a lipid source, metabolic stability, and sufficiently high lipophilicity. In terms of a "ball park" estimate, the log P of a candidate drug needs to be $>5$, with a TG solubility of at least $50 \mathrm{mg} / \mathrm{mL}$, before lymphatic transport is likely be a major contributor to bioavailability. ${ }^{116,133}$ Therefore, although lymphatic transport is a biological process, the potential for it to contribute to oral bioavailability can be reasonably estimated from consideration of the relevant physicochemical properties of the drug.

A common difficulty in assessing the role of lymph transport in enhanced postprandial absorption arises because conclusions are often indirectly drawn from consideration of plasma concentration-time profiles. The physicochemical properties of the drug should al ways be considered when estimating the potential contribution of Iymphatic transport to enhanced postprandial bioavailability, and animal studies are typically required to confirm Iymphatic transport. ${ }^{132,134}$

\section{Case Studies: Dissolution, Solubilization, and Lymphatic Transport}

Notwithstanding the potential nonspecific binding of drugs to constituent parts of a meal, the effect of lipids on postprandial drug absorption can often be assessed by considering enhanced dissolution/solubilization, modulation of gastric emptying, and stimulation of lymphatic transport. The following case studies are selected examples for which enhanced postprandial oral bioavailability has been assessed in this manner (Table 1).

Griseofulvin-The classic example of enhanced postprandial bioavailability is griseofulvin. ${ }^{135}$ Bates et al. ${ }^{61-63}$ dem-
Table 2-Effect of Food on the Oral Bioavailability of Danazol and the Effect of Bile Salt Concentration on the In Vitro Equilibrium Solubility and Initial Dissolution Rate of Danazola

\begin{tabular}{lcc}
\hline & \multicolumn{2}{c}{ Bioavailability Parameter $\mathrm{r}^{\mathrm{a}, \mathrm{b}}$} \\
\cline { 2 - 3 } \multicolumn{1}{c}{ Administration } & Plasma AUC $(\mathrm{ng} \mathrm{h} / \mathrm{mL})$ & $C_{\max }(\mathrm{ng} / \mathrm{mL})$ \\
\hline Fasted Capsule & $204 \pm 125$ & $37 \pm 16$ \\
Fed capsule & $639 \pm 259$ & $101 \pm 42$ \\
Fasted MG emulsion & $779 \pm 189$ & $155 \pm 55$ \\
Fed MG emulsion & $844 \pm 194$ & $126 \pm 56$ \\
\hline
\end{tabular}

\begin{tabular}{ccc}
\hline & \multicolumn{2}{c}{ Physicochemical Parameters } \\
\cline { 2 - 3 } NaTC Conc $(\mathrm{mM})$ & Solubility $(\mu \mathrm{g} / \mathrm{mL})$ & Initial $\mathrm{DR}^{b, c}\left(\mu \mathrm{g} / \mathrm{mL} / \mathrm{min} \times 10^{3}\right)$ \\
\hline 3.75 & 0.79 & 0.3 \\
15 & 6.10 & 1.8 \\
30 & 21.7 & 6.3 \\
\hline
\end{tabular}

${ }^{a}$ Results were determined after administration of $100 \mathrm{mg}$ of danazol to human subjects $(n=11)$ and are expressed as mean \pm SD. ${ }^{b}$ The data are from refs 58 and $137 .{ }^{\circ} \mathrm{DR}$, Dissolution rate.

onstrated that the enhanced solubility and dissolution of griseofulvin in supramicellar concentrations of bile salts was the primary basis for the enhanced absorption. Recently, it was demonstrated in vitro that although addition of lecithin to $\mathrm{NaC}$ micelles increased the solubility of griseofulvin up to 5 -fold, only marginal effects were observed on dissolution rate. ${ }^{136}$ The lack of a concomitant increase in dissolution rate with increasing solubility was ascribed to a progressive decrease in the diffusion coefficient of the mixed micelle due to a lecithin concentration-dependent increase in its size. Within the lecithin and bile salt concentration range studied, the coexistence of simple and mixed micelles impacted on the relative partitioning of griseofulvin between these micellar structures, that is, increasing amounts of drug solubilized in the mixed micelles as the molar ratio of lecithin to bile salt increased. However, the concentration of "free" drug in the various bile salt/lecithin solutions remained relatively constant at $\sim 10 \%$ of the total concentration.

Danazol-Danazol is a high-dose, poorly water-soluble steroid that exhibits highly variable oral bioavailability in the fasted state. The oral bioavailability from a capsule formulation increased 3-fold when administered 30 min after ingestion of a fatty meal (Table 2). ${ }^{137}$ The improved absorption after postprandial administration of the capsule was attributed, in part, to increased dissolution and improved solubilization within the postprandial GI contents. When the same dose of danazol was administered as a MG-based lipid emulsion to either fed or fasted subjects, the plasma levels were similar to those achieved after postprandial administration of the capsule formulation (Table 2 ). The apparently optimal performance of the MG-based emulsion formulation in the fasted subjects was ascribed to the triggering of an effective "postprandial" Gl environment.

In vitro studies demonstrated a 10-fold increase in the solubility of danazol in $15 \mathrm{mM} \mathrm{NaTC}$ compared with buffer 
Table 3-Oral Bioavailability Parameters for Halofantrine $\mathrm{HCl}$ After Administration to Either Fasted or Fed Healthy Human Subjects and Fasted or Fed Beagle Dogs and the Effect of Bile Salt Concentration on the In Vitro Equilibrium Solubility and Intrinsic Dissolution Rate of Halofantrine $\mathrm{HCl}$

\begin{tabular}{lccccc}
\hline \multirow{2}{*}{$\begin{array}{c}\text { Bioavailability } \\
\text { Parameter }\end{array}$} & \multicolumn{2}{c}{ Human Subjects $^{b}$} & & \multicolumn{2}{c}{ Beagle Dogs $^{c}$} \\
\cline { 2 - 3 } \cline { 5 - 6 } \cline { 5 - 6 } & Fasted & Fed & & Fasted & Fed \\
\hline $\begin{array}{l}\text { Plasma AUC }(\mathrm{mg} \mathrm{h} / \mathrm{L}) \\
C_{\max }(\mathrm{ng} / \mathrm{mL})\end{array}$ & $3.9 \pm 2.6$ & $11.3 \pm 3.5$ & & $4.2 \pm 2.7$ & $51.5 \pm 9.4$ \\
\hline & $184 \pm 115$ & $1218 \pm 464$ & $275 \pm 156$ & $5540 \pm 2107$ \\
\hline \multicolumn{3}{c}{ Physicochemical Parameter }
\end{tabular}

\begin{tabular}{lcc}
\cline { 2 - 3 } NaTC Conc & Solubility $(\mu \mathrm{g} / \mathrm{mL})$ & Intrinsic $\mathrm{DR}^{d}\left(\mu \mathrm{g} / \mathrm{s} / \mathrm{cm}^{2}\right)$ \\
\hline $3.75 \mathrm{mM}$ & 2.1 & 0.0061 \\
$3.75 \mathrm{mM}$ + lecithine & 37.3 & 0.0722 \\
$15 \mathrm{mM}$ + lecithin & 2252 & 1.2243 \\
$30 \mathrm{mM}$ + lecithin & 4513 & 2.2769
\end{tabular}

${ }^{a}$ Data are presented as mean \pm SD and are from refs 67 and $143 .{ }^{b} n=6$. ${ }^{c} n=3 .{ }^{d} \mathrm{DR}$, Dissolution rate. ${ }^{e} \mathrm{NaTC}$ : lecithin molar ratio of $4: 1$.

control (Table 2), and 3- and 10-fold improvements in dissolution under representative postprandial simple ${ }^{58}$ and mixed micellar ${ }^{138}$ solutions, respectively. The magnitude of the increase in the dissolution rate and solubility of danazol at bile salt concentrations $>5 \mathrm{mM}$ is consistent with the increased postprandial bi oavailability. Consideration of contact angle measurements in the context of the solubility and dissolution data indicated that solubilization, rather than enhanced wetting, was the primary basis for increased dissolution of danazol. 58

$\alpha$-Tocopheryl Nicotinate-The fat-soluble vitamins, including $\alpha$-tocopherol, have poor oral bioavailability and largely gain access to the systematic circulation via the intestinal lymphatics. As $\alpha$-tocopherol is unstable due to oxidation of the phenol group, numerous prodrug strategies have been employed to combat both its low bioavailability and poor stability. ${ }^{139-142}$ Hasegawa et al. ${ }^{140}$ studied the effect of food on the bioavailability of a nicotinate prodrug of vitamin $E(\alpha-$ tocopheryl nicotinate) in beagles and humans. When $\alpha$-tocopheryl nicotinate was administered postprandially to beagles, there was a 5-fold enhancement in bioavailability compared with administration in the fasted state. In humans, the bioavailability of $\alpha$-tocopheryl nicotinate improved 28 -fold when administered in the fed state. These improvements in bioavailability of $\alpha$-tocopheryl nicotinate after postprandial administration were a function of both improved dissolution and solubilization, which improved absorption into the portal blood, as well as recruitment of intestinal lymphatic transport as a contributor to oral bioavailability. ${ }^{118,132}$

Halofantrine- $\mathrm{Hal}$ ofantrine hydrochloride $(\mathrm{Hf} \cdot \mathrm{HCl})$ is a highly lipophilic phenanthrene derivative (calc. $\log \mathrm{P}, 8.5)$ used for the treatment of drug-resistant malaria. When administered postprandially, bioavailability increased threefold in humans, ${ }^{143}$ and 10-fold in beagles (Table 3). 67 Studies conducted in lymph-fistulated rats demonstrated 5\% transport, 144 indicating that the increased postprandial bioavailability was unlikely to be a function of Iymphatic transport.

In vitro solubility and dissolution studies of $\mathrm{Hf} \cdot \mathrm{HCl}$ indicated that these parameters were very sensitive to bile salt concentration and micellar composition. For example, the solubility of $\mathrm{Hf} \cdot \mathrm{HCl}$ in simple bile salt micelles representative of the fasted state (3.75 mM NaTC) was $2.1 \mu \mathrm{g} / \mathrm{mL}$. In conditions representative of the fed state, such as $15 \mathrm{mM}$ NaTC mixed micelles, the solubility increased to $>2000 \mu \mathrm{g} /$ $\mathrm{mL} .{ }^{67}$ The solubility and dissolution rate of $\mathrm{Hf} \cdot \mathrm{HCl}$ as a function of bile salt concentration are shown in Table 3. There was a marked increase in these parameters at post-cmc bile salt concentrations, with the magnitude of the increase being much larger than observed with danazol. Because of the similarity between the solubility and dissolution rate profiles, it is likely that enhanced solubilization, rather than wetting, was the basis for the increased dissolution of $\mathrm{Hf} \cdot \mathrm{HCl}$. These data indicate that the increased postprandial absorption of $\mathrm{Hf} \cdot \mathrm{HCl}$ is consistent with the dramatically enhanced dissolution and solubilization of the compound in the presence of mixed bile salt micelles.

Atovaquone-Atovaquone is a highly lipophilic antiprotozoal drug that is slowly and irregular absorbed after oral administration in the fasted state. Administration of a tablet formulation with either a low or high fat breakfast improved bioavailability 3.3-fold and 5.3-fold, respectively. ${ }^{145}$ The aqueous solubility of atovaquone is $<0.1 \mu \mathrm{g} / \mathrm{mL}$, which increased to $\sim 100 \mu \mathrm{g} / \mathrm{mL}$ under simulated postprandial conditions. The potential lymphatic transport of atovaquone in the fed state was investigated by isolating chylomicrons from the plasma and analyzing for the presence of drug. This is a useful approach for noninvasively identifying the occurrence of intestinal lymphatic transport in humans, although the rapid plasma clearance of chylomicrons and lipophilic drugs requires validation on a case-by-case basis. Atovaquone was not detected with this approach, suggesting that lymphatic transport was not a contributing postprandial absorption pathway. These data indicate that the basis for the enhanced absorption of atovaquone was most likely the enhanced solubilization capacity of the postprandial GI environment leading to enhanced portal blood absorption.

Retinoic Acid Derivatives-Etretinate is an orally active retinoid that undergoes first pass deesterification to form etretin, which subsequently isomerizes to form isoetretin. ${ }^{146}$ The oral bioavailability of etretinate increased 3-5-fold when administered with a high fat meal or milk compared with fasted administration. ${ }^{146,147}$ The amount of metabolite formed (defined by the area under the metabolite plasma concentration-time curve) was unchanged after administration of parent compound in either the fed or fasted state, indicating that coadministration of etretinate with food significantly increased the amount of parent drug absorbed, but appeared to reduce the extent of metabolism. Due to the structural similarity with Vitamin A, it was speculated that solubilization of etretinate in the postprandial intestinal environment may have facilitated both portal blood absorption and lymphatic transport. I sotretinoin is another orally active retinoid where bioavailability is also significantly enhanced when administered postprandially. ${ }^{148}$

\section{Predictive Approaches to Assessing Lipid-Enhanced Bioavailability}

Physicochemical properties, such as solubility in aqueous, organic and lipidic solvents, and octanol/water partition coefficients, are a useful starting point in identifying possible absorption problems when used in combination with various absorption models. ${ }^{19-21}$ Analysis of these data can often identify whether absorption of a poorly water-soluble drug may be sensitive to the changes that occur in the postprandial Gl tract. (Recent evidence has identified oxidative metabolism in intestinal villous tips and a P-glycoprotein countertransport process as potential contributors to the poor oral bioavailability of cyclosporine, which is poorly water soluble. ${ }^{150,151}$ Furthermore, it appears that some lipidic derivatives may inhibit the P-glycoprotein countertransport system, thereby enhancing the bioavailability of compounds subject to this efflux system. ${ }^{152,153}$ Although further data and examples are required before these findings can be more widely assessed, they offer an interesting new perspective when assessing the limited bioavailability of poorly water-soluble drugs.) 
The solubility and dissolution rate of drugs can be readily determined as a function of bile salt concentration, ${ }^{149}$ and these results can then be equated with the likely fasted and fed conditions that occur in vivo. These measurements are typically conducted with a single bile salt, such as NaTC or $\mathrm{NaGC}$, although Staggers et al. ${ }^{34}$ suggested a mixture of 10 bile salts to more accurately represent the in vivo situation. As biliary lipids and lipid digestion products are required to form mixed micel lar systems, there is also merit in examining these more complex micellar systems. However, financial and logistical constraints limit the number of components used in such experiments, particularly for dissolution media for which large volumes are often required.

The development of lipid digestion models is an area requiring further research because these models offer a means for following the passage of lipophilic drugs through the various phases associated with lipid digestion. Reports exist where in vitro lipid digestion models ${ }^{154,155}$ have been used to assess the rate and extent of transfer of drugs from a prospective formulation, through the respective colloidal phases, to the final mixed micellar phase. ${ }^{156}$ It has been proposed that the rate of transfer may be a crucial ratedetermining step in the absorption of highly lipophilic drugs, particularly from lipid-based formulations. ${ }^{156}$

There are various animal models available for the confirmation of intestinal lymphatic transport ${ }^{134,157}$; however, the best first step is estimation of the potential for transport from consideration of the partition coefficient and lipid solubility of the drugs. If such calculations indicate that Iymphatic transport may be a contributor to oral bioavailability, then further confirmatory experiments should be undertaken. These studies are especially important to identify optimal lipid-based formulations for such drugs.

\section{The Effect of pH on Drug Absorption}

As aspects of drug absorption and dosage form performance are sensitive to the $\mathrm{pH}$ environment of the GI tract, postprandial changes in $\mathrm{GI}$ pH values can influence drug absorption. The basal values and temporal changes that occur in $\mathrm{Gl} \mathrm{pH}$ profiles and the physicochemical basis by which these altered $\mathrm{pH}$ profiles can impact on drug absorption and bioavailability are now described.

Basal Gastric Acid and Pancreatic Bicarbonate Secretion-The human stomach contains approximately one billion parietal cells that produce $\mathrm{HCl}$ at a concentration of $\sim 160 \mathrm{mE} \mathrm{q} / \mathrm{L} .{ }^{158}$ In the fasted state, basal gastric acid secretion is $\sim 2-4 \mathrm{mmoL} / \mathrm{h}$ in men and slightly lower in women. ${ }^{159,160}$ The exocrine secretions of the pancreas consist of a highvolume aqueous secretion containing bicarbonate ion and a low-volume aqueous secretion containing digestive enzymes. There is $\sim 1 \mathrm{~L}$ of pancreatic fluid secreted daily into the duodenum, with the alkaline component ranging between 0.2 and $0.8 \mathrm{~L} .158$ Basal secretion of bicarbonate is $1-2 \%$ of the maximal secretory rate, which can be induced by exogenous administration of secretin. ${ }^{161}$ A cyclical pattern of basal pancreatic secretion was demonstrated in humans and consisted of brief increases in bicarbonate secretion every $1-2 \mathrm{~h}$ that were associated with the interdigestive migrating motor complex. ${ }^{162-164}$ The flow rate typically increased from $0.3 \mathrm{~mL} /$ $\mathrm{min}$ in the resting state to $4.0 \mathrm{~mL} / \mathrm{min}$ during stimulation. ${ }^{165}$ When the flow rate was at a lower value of $0.6 \mathrm{~mL} / \mathrm{min}$, the concentration of bicarbonate was $\sim 25 \mathrm{mE} \mathrm{q} / \mathrm{L}$, resulting in a secretion rate of $\sim 1 \mathrm{mEq} / \mathrm{h} .{ }^{166}$

Fasting Upper GI pH in Young Healthy SubjectsFasting gastric $\mathrm{pH}$ has been well studied, and the generally accepted value is between 1.5 and $2 .{ }^{167-170}$ In a Heidelberg capsule study of 24 young healthy volunteers, Dressman et
Table 4-Compilation of Regional Intestinal pH Values in Healthy Human Subjects in Pre- or Postprandial States ${ }^{a}$

\begin{tabular}{ccl}
\hline Intestinal Site & Preprandial pH & \multicolumn{1}{c}{$\begin{array}{c}\text { Postprandial } \mathrm{pH} \\
\text { (time after meal ingestion) }\end{array}$} \\
\hline Duodenum & $4.0-5.4$ & $4.9-5.9(0-240 \mathrm{~min})$ \\
& $5.8-6.5$ & $5.3-6.1(180-240 \mathrm{~min})$ \\
Jejunum & $6.4 \pm 0.6$ & $4.5-5.5(0-60 \mathrm{~min})$ \\
& $4.4-6.5$ & $5.2-6.0(0-180 \mathrm{~min})$ \\
Ileum & $6.6 \pm 0.5$ & $6.2 \pm 0.2(0-60 \mathrm{~min})$ \\
& $6.8-8.0$ & $6.8-7.8$ \\
& $7.4 \pm 0.4$ & $6.8-8.4$ \\
\hline
\end{tabular}

a Values are means $\pm \mathrm{SD}$ or $\mathrm{pH}$ range (from ref 180).

al. ${ }^{170}$ observed a median fasted gastric $\mathrm{pH}$ of 1.7 [inter-quartile range (IQR), 1.4-2.1]. During the $1 \mathrm{~h}$ observation period employed in the study, episodes of elevated gastric $\mathrm{pH}$ were recorded in the majority of subjects. For example, the fasting $\mathrm{pH}$ was $<2$ for $68 \%$ of the time and $<3$ for $90 \%$ of the time, whereas $\mathrm{pH}$ values $>4$ were evident $6 \%$ of the time, with readings as high as $\mathrm{pH} 6$ rarely observed.

The fasting $\mathrm{pH}$ profile of the duodenum has been most extensively measured in the duodenal bulb, ${ }^{171-174}$ with the variability in reported values ( $\mathrm{pH} 2.4$ to 6.8) being due to the wide temporal and positional fluctuations in this area of the duodenum. A smaller number of studies have investigated the $\mathrm{pH}$ in the mid to distal region of the duodenum, $167,170,174,175$ with a median $\mathrm{pH}$ in the mid-distal duodenum of young healthy volunteers reported to be 6.1 (IQR, 5.8-6.5). ${ }^{170}$

The fasting $\mathrm{pH}$ of the jejunum is typically reported to range between 6 and 7.176 However, Ovesen et al. ${ }^{174}$ determined the fasting $\mathrm{pH}$ in the proximal jejunum to range between 5.9 and 6.2 , Watson et al. ${ }^{172}$ described a range of jejunal $\mathrm{pH}$ values between 3.1 and 6.5, and Zentler-M unro et al. ${ }^{178}$ reported the fasting $\mathrm{pH}$ to be $<5.0$ for $17 \%$ of the time. Reported values of $\mathrm{pH}$ in the distal ileum in the fasted state range between 6.5 and 8. ${ }^{171,179}$ Reported regional intestinal $\mathrm{pH}$ values in healthy human subjects in preprandial or postprandial states are compiled in Table 4.

Variation in Upper GI pH Values-Gastric pH is sensitive to increasing age, pathological conditions and druginduced changes. Although the majority of elderly people exhibit gastric $\mathrm{pH}$ profiles similar to younger people, $\sim 10-$ $20 \%$ of the elderly population exhibit either diminished (hypochlorhydria) or no gastric acid secretion (achlorhydria), leading to basal gastric $\mathrm{pH}$ values $>5.0 .^{181-184}$ In a recent study of 79 healthy elderly subjects ( $71 \pm 5$ years), the observed median fasting gastric $\mathrm{pH}$ was 1.3 (IQR, 1.1-1.6), although in five achlorhydric subjects, the median fasting $\mathrm{pH}$ was as high as 7.1.185 Duodenal $\mathrm{pH}$ was also slightly higher in healthy elderly subjects compared with younger subjects. The overall median fasting duodenal $\mathrm{pH}$ of healthy subjects was 6.5 (IQR, 6.2-6.7), whereas in achlorhydric subjects it was 6.8. ${ }^{185}$

Pathological conditions in which there is a decrease in gastric acid secretion leading to el evated gastric $\mathrm{pH}$ values include pernicious anemia184 and AIDS. ${ }^{186}$ Inhibition of gastric acid secretion with either $\mathrm{H}_{2}$ receptor antagonists or proton pump inhibitors can result in marked increases in gastric pH. Although gastric $\mathrm{pH}$ can be considerably elevated in response to histamine $\mathrm{H}_{2}$ antagonist therapy, there are usually periods between doses where gastric $\mathrm{pH}$ may be relatively acidic. In contrast, omeprazole therapy can completely inhibit acid secretion on a round-the-clock basis. ${ }^{187}$

Temporal Pattern of Gastric and Duodenal pH after Meals-After ingestion of a meal, gastric acid secretion promptly increases above basal rates such that within 90 min after ingestion, the rates of acid secretion approach maximal capacity. Average acid secretion after a meal range between 
20 and $30 \mathrm{mmoL} / \mathrm{h}$, with values for men typically being a little higher than for women. ${ }^{188-190}$ Total postprandial pancreatic output is $\sim 60-70 \%$ of the output attained in response to maximal stimulation with intravenous infusion of cholecystokinin, resulting in a bicarbonate secretion rate of $\sim 15-17$ $\mathrm{mEq} / \mathrm{h} .{ }^{191}$ The secretion of the alkaline pancreatic fluid is largely regulated by the amount of acid entering the duodenum. The $\mathrm{pH}$ of the alkaline fluid entering the duodenum at high output rates is $\sim 8,192$ and after mixing with the bile and alkaline fluids secreted by the mucosal lining of the intestine, the acidic chyme entering the duodenum is partially neutralized.

After ingestion of a meal, gastric $\mathrm{pH}$ is distinctly but briefly elevated in spite of increased gastric acid secretion, which is attributed to the diluting and buffering effect of the ingested food components. ${ }^{159}$ After gastric emptying occurs, the gastric $\mathrm{pH}$ gradually declines until the fasted-state $\mathrm{pH}$ environment has been reestablished. The decline in gastric $\mathrm{pH}$ is a function of both the ability of the meal to stimulate gastric acid secretion and the rate at which the meal is emptied from the stomach.

Few studies have measured gastric $\mathrm{pH}$ after ingestion of relatively normal solid/liquid meals. ${ }^{167,170,193}$ In one study, Malagelada et al. ${ }^{167}$ studied gastric $\mathrm{pH}$ in six healthy subjects by an aspiration technique after ingestion of a meal containing ground steak, bread, butter, vanilla ice cream with chocolate syrup, and water $(458 \mathrm{Kcal})$. The $\mathrm{pH}$ of the gastric contents after ingestion of the meal was $\sim 5.0$, reflecting both the dilution and buffering effects of the meal. Sixty minutes after meal ingestion, the $\mathrm{pH}$ had fallen to $<3.0$, and after $120 \mathrm{~min}$, the $\mathrm{pH}$ had returned to values of $<2.0$. In a similar manner, Dressman et al. ${ }^{170}$ studied post-prandial gastric pH in 24 young heal thy men and women after administration of a meal containing hamburger, bread, hash brown potatoes, and milk (1000 Kcal). During the meal, gastric pH increased to a median value of 5.0 (I QR , 4.3-5.4). The highest recorded pH value was a peak value of 6.7 (IQR, 6.4-7.0) that occurred within the first $5 \mathrm{~min}$ of eating. By constantly monitoring gastric $\mathrm{pH}$ values, it was possible to determine the time course of the reestablishment of gastric $\mathrm{pH}$, and it took $11 \pm 10 \mathrm{~min}$

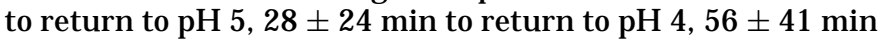
to return to $\mathrm{pH} 3$, and $107 \pm 70$ min to return to $\mathrm{pH} 2$. Similar profiles were observed in healthy elderly subjects for whom the median $\mathrm{pH}$ during the meal was 4.9 (IQR, 3.9-5.5), with a peak $\mathrm{pH}$ value of 6.2 (5.8-6.7). ${ }^{185}$ However, the time required for gastric $\mathrm{pH}$ to return to 2.0 was significantly longer when compared with the younger subjects.

There is considerable variability in the $\mathrm{pH}$ of the duodenal bulb in the first 60-min period after ingestion of a meal, with values ranging between 3.8 and 6.1.171-174 Typically, the pH of the duodenal bulb has returned to fasting $\mathrm{pH}$ values within $3 \mathrm{~h}$ of meal ingestion. There is less data available about the postprandial $\mathrm{pH}$ in the mid-to-distal region of the duodenum. ${ }^{167,170,174}$ Dressman et al. ${ }^{170}$ noted that during ingestion of a standard solid-liquid meal by young healthy subjects, the overall median $\mathrm{pH}$ of the mid-to-distal portion of the duodenum was 6.3 (IQR, 6.0-6.7) and the overall post-prandial median $\mathrm{pH}$ over a period of $4 \mathrm{~h}$ was 5.4 (IQR, 5.0 to 5.7). Comparatively, in healthy elderly subjects, the overall median $\mathrm{pH}$ during meal ingestion was 6.5 (IQR, 6.4-6.7) and the overall postprandial median pH was 5.6 (IQR, 5.1-6.0). These data indicate that a brief period of elevated duodenal $\mathrm{pH}$ occurs upon ingestion of the meal that can be attributed to the cephalic phase of pancreatic bicarbonate secretion. ${ }^{194}$ When considered in an overall context, the $\mathrm{pH}$ in the postprandial phase in the duodenum is lower than that in the fasted state.

Few studies have reported the $\mathrm{pH}$ of the jejunum in the fed state. In one study where a Lundh test meal (dried milk, vegetable oil, and dextrose) was administered to healthy subjects, the $\mathrm{pH}$ of the proximal jejunum increased to 6.5 at 30 min after meal ingestion and then decreased to 5.7 at $3 \mathrm{~h}$ after ingestion. ${ }^{174}$ Similarly, Temple et al. ${ }^{195}$ reported that the jejunal pH was 5.9 at 30 min after ingestion of a test meal and also decreased to a value of 4.7 at $2 \mathrm{~h}$ after ingestion. The $\mathrm{pH}$ of the ileum in the fed state has not been studied.

\section{Impact of Differences in Pre- and Postprandial Gl $\mathrm{pH}$ on Bioavailability}

The rate of dissolution, chemical stability, and intrinsic permeability of a drug may be affected by temporal changes in $\mathrm{Gl} \mathrm{pH}$. In the following sections we primarily address the role of the changing $\mathrm{Gl} \mathrm{pH}$ environment on the intrinsic factors related to drug absorption, rather than the $\mathrm{pH}$ dependence of the various extrinsic formulation-related factors.

Drug Solubility and Dissolution-The $\mathrm{pH}$ differences in the contents of the upper Gl tract between fed and fasted states can influence the dissolution and absorption of weakly acidic and basic drugs. The dissolution rate of weak bases is typically greater in gastric fluids than in the intestine in the fasted state, whereas that of weak acids is at a minimum in the stomach and increases as undissolved drug is transported to the less acidic regions of the intestine. Therefore, el evation of gastric $\mathrm{pH}$ following a meal may enhance the dissolution of a weak acid in the stomach but inhibit that of a weak base. Furthermore, because food inhibits the rate of gastric emptying, ${ }^{159}$ prolonged retention in the stomach may increase the proportion of drug that dissolves prior to passage into the small intestine. The primary site of drug absorption is usually the small intestine because of its greater mucosal surface area and range of transport mechanisms, so the class of drugs most vulnerable to $\mathrm{pH}$-related changes in postprandial absorption are poorly water-soluble weak bases.

Drug Release-The disintegration and dissolution of some coating materials used on tablets may be $\mathrm{pH}$ dependent, thereby affecting drug release. Examples of such polymers include, among others, shellac, polyvinylacetal diethylaminoacetate, and amphoteric polyvinyl pyridine derivatives. F or example, pH-dependent disintegration of the water-proof coating of sugar-coated tablets of chloramphenical and metronidazole led to reduced bioavailability in subjects with elevated gastric $\mathrm{pH} .196,197$ Modern enteric coatings, such as cellulose acetate phthalate, polyvinylacetate phthalate, and the polymethacrylates, rely on their pH-solubility profiles to provide enteric protection. These coatings are virtually insoluble at acid $\mathrm{pH}$ but begin to dissolve rapidly at characteristic pH values between 4.5 and 8 (depending on the polymer backbone, degree of substitution, and the $\mathrm{pK}_{a}$ of the substituent species). The pH sensitivity of coating-dissolution profiles suggests that small alterations in $\mathrm{Gl} \mathrm{pH}$ could significantly affect formulation performance because higher than normal gastric $\mathrm{pH}$ could result in premature release of drug in the stomach, and lower than normal intestinal $\mathrm{pH}$ values could retard drug release with the potential for compromising bioavailability. ${ }^{198}$ For example, Qureshi et al. ${ }^{199}$ found that the $T_{\max }$ (time to maximum concentration) from enteric-coated ketoprofen tablets was shorter and the $\mathrm{C}_{\max }$ (maximum concentration) was higher in subjects pretreated with omeprazole (to el evate the gastric $\mathrm{pH}$ ) compared with control subjects; these results are consistent with initial drug release in the stomach.

Changing $\mathrm{Gl} \mathrm{pH}$ values may also impact on the permeability of insoluble film coatings used to provide controlled release of medicaments as well as on the overall dissolution and drug release patterns from various matrix-based sustained- 
release formulations. For example, the release of ephedrine and amphetamine from a peroral depot polystyrene ionexchange resin was high when in the stomach, but decreased during transit through the small intestine.200 Changing solution $\mathrm{pH}$ values influences the liberation of drugs embedded in slowly eroding FA-based wax matrices (e.g., butyl stearate, saccharose monostearate, glycerin monostearate) by affecting the hydrolysis rate of FA esters. ${ }^{200}$ Kohri et al. ${ }^{201}$ evaluated the effect of gastric $\mathrm{pH}$ on the bioavailability of dipyridamole from $\mathrm{pH}$-dependent sustained-release granules (drug release decreased with increasing $\mathrm{pH}$ ). When administered to gastric acidity-controlled rabbits, a 5-fold decrease in $\mathrm{C}_{\max }$ and a fourfold decrease in AUC (area under the curve of concentration versus time) was observed in the group with low gastric acidity compared with the group with high gastric acidity.

Formulation excipients can also cause drug release to vary with $\mathrm{pH}$. For example, various calcium salts are used as diluents or disintegrants in solid dosage forms, and these salts dissolve in gastric fluids via reaction with hydrochloric acid. The solubility of dicalcium and tricalcium phosphate is decreased 10-fold when the solution $\mathrm{pH}$ is increased from 1.0 to 2.0.202 Therefore, rapid disintegration of tablets containing these excipients only occurs under acidic conditions. A pHdependent interaction of weak bases with the disintegrant croscarmellose sodium has been described (interaction increased with increasing $\mathrm{pH}),{ }^{203}$ leading to the suggestion that the bioavailability of such formulations may be compromised at elevated $\mathrm{pH}$. In terms of soft gelatin capsules, shell dissolution is dependent on $\mathrm{pH}$ as evidenced by the reported dissolution rate decrease of about 2-3-fold as $\mathrm{pH}$ was increased from 1.0 to 3.0 (after pH 3.0, the rate was essentially $\mathrm{pH}$ independent). ${ }^{204}$

Drug Stability-The stability of acid-labile drugs is a major consideration when interpreting oral bioavailability profiles under conditions of potentially varied $\mathrm{pH}$. Elevated gastric $\mathrm{pH}$ may afford enhanced bioavailability of acid-labile drugs such as penicillin, erythromycin, and digoxin. For example, under acidic conditions, digoxin is hydrolyzed to the digoxigenin aglycone derivative, which has reduced pharmacodynamic activity. In a recent bioavailability study, Cohen et al. ${ }^{205}$ found that pentagastrin (which increases gastric acid secretion) reduced the urinary excretion of unchanged digoxin from 34 to $21 \%$ of the administered dose, whereas, omeprazole (which reduces gastric acidity) increased urinary excretion to $47 \%$ of the administered dose.

Intestinal Permeability-F or ionic drugs, the fraction of drug available for absorption may be altered by changing $\mathrm{pH}$ values. Because drugs absorbed by a passive, transcellular mechanism are predominantly absorbed in their un-ionized form, the $\mathrm{pH}$ in the intestinal lumen relative to the $\mathrm{pK}_{\mathrm{a}}$ of the drug is an important determinant of the absorption rate. According to the $\mathrm{pH}$-partition theory, ${ }^{206}$ a weak base would be best absorbed at $\mathrm{pH}$ values above the $\mathrm{pK}_{\mathrm{a}}$, whereas a weak acid would be best absorbed at $\mathrm{pH}$ values below the $\mathrm{pK}_{a}$, providing there are no solubility limitations. Therefore, the half-maximal rate of absorption occurs at $\mathrm{pH}$ values close to their $\mathrm{pK}_{\mathrm{a}}$. In such cases, Winne 207 demonstrated that the following equation (depending on whether the compound is an acid or base) can describe the absorption profile of sufficiently lipophilic drugs.

$$
\mathrm{pH}(\max / 2)=\mathrm{pK}_{\mathrm{a}} \pm \log \left(1+\mathrm{P}_{\mathrm{m}} / \mathrm{P}_{\mathrm{aq}}\right)
$$

where $P_{m}$ is the membrane permeability, and $P_{a q}$ the aqueous boundary layer permeability (as a first approximation, $\mathrm{P}_{\mathrm{m}}$ / $\mathrm{P}_{\text {aq }}$ can be represented by the octanol/water partition coefficient). For drugs with half-maximal $\mathrm{pH}$ absorption data in the range of small intestinal $\mathrm{pH}$ values, the absorption rate would be expected to be sensitive to small shifts in intestinal $\mathrm{pH}$ (with up to a 10-fold change in rate with a one unit shift in $\mathrm{pH}$ ). Furthermore, if a drug is incompletely and variably absorbed, then minor changes in lumenal $\mathrm{pH}$ would be expected to result in changes in the rate and extent of absorption. Examples of such compounds include some diuretics, antibacterial agents used to treat urinary tract infections, and various nonsteroidal antiinflammatory compounds.

The effect of lumenal $\mathrm{pH}$ on intestinal permeability has been documented for several drugs for which there are solubility limitations to absorption, ${ }^{207-210}$ with intestinal permeability being directly related to the rate of absorption. ${ }^{209}$ For drugs that are incompletely absorbed, altered permeability resulting from a change in intestinal $\mathrm{pH}$ would be expected to translate into an alteration in the rate of absorption. Drugs with $\mathrm{pH}$-dependent permeability include aspirin, ${ }^{211} \alpha$-methyl dopa, ${ }^{212}$ and cimetidine. ${ }^{213}$ For example, data from intestinal perfusions conducted in humans indicated that the effective permeability of $\alpha$-methyl dopa was maximal at $\mathrm{pH} 6.0$ and decreased as the $\mathrm{pH}$ of the perfusion medium was either decreased to $\mathrm{pH} 4.5$ or increased to $\mathrm{pH}$ 7.4.

\section{Case Studies: Effect of Changing GI pH on Drug Absorption}

It is important that poorly water-soluble weakly basic drugs dissolve rapidly in the stomach because dissolution of undissolved drug in the intestine may be too low to permit complete absorption. Ketoconazole is a weak dibasic drug $\left(\mathrm{pK}_{\mathrm{a}_{1}}=6.51\right.$, $\left.\mathrm{pK}_{\mathrm{a}_{2}}=2.94\right)$ that exhibits $\mathrm{pH}$-dependent dissolution. At $\mathrm{pH}$ values of $<3$, in vitro dissolution was rapid, with $>85 \%$ dissolved within $5 \mathrm{~min}$, whereas at $\mathrm{pH} 6$, only $10 \%$ dissolved after 1 h. ${ }^{214}$ Consequently, absorption of ketoconazole would be expected to be influenced by those factors that affect gastric acidity. Piscitelli et al. ${ }^{215}$ determined that when ranitidine was administered concomitantly with ketoconazole to titrate gastric $\mathrm{pH}$ to 6.0 , the mean plasma $A U \mathrm{C}^{0-12 \mathrm{~h}}$ values decreased to $1.6 \mu \mathrm{g} \mathrm{h} / \mathrm{mL}$ from $37.1 \mu \mathrm{g} \mathrm{h} / \mathrm{mL}$, and mean $\mathrm{C}_{\max }$ values were correspondingly reduced from 8.2 to $0.6 \mu \mathrm{g} / \mathrm{mL}$. Similar results were also observed when cimetidine was employed to raise gastric $\mathrm{pH}$ during concomitant ketoconazole therapy. ${ }^{216}$ Plasma concentration-time profiles of ketoconazole when administered to fasting or fed subjects, after pretreatment with glutamic acid, after pre-treatment with cimetidine and bicarbonate to induce a simulated achlorhydria, or after pre-treatment with glutamic acid in the simulated achlorhydric state are shown in Figure 2.217 The marked changes in the plasma profiles are readily interpreted in the context of the expected solubility of the weakly basic drug in the gastric environment under these different treatment regimens.

Ogata et al. 218 investigated the bioavailability of cinnarizine in subjects with low and high gastric acidity. Cinnarizine is a weak base that readily dissolves at $\mathrm{pH} 1$, although the solubility is $<10 \mu \mathrm{g} / \mathrm{mL}$ at $\mathrm{pH}$ values $>5$. The maximum plasma concentration and plasma AUC data for cinnarizine decreased by almost $85 \%$ in subjects with el evated gastric pH compared with those exhibiting low gastric acidity.

Lebsack et al. ${ }^{219}$ evaluated the effect of gastric acidity on the oral absorption of enoxacin, which is a quinol one antibiotic. Coadministration of ranitidine significantly decreased the mean enoxacin plasma $\mathrm{C}_{\max }$ by $45 \%$ and the AUC values by $32 \%$, whereas this effect was abolished when pentagastrin was used to maintain a low gastric pH environment. E noxacin is very soluble in solutions with $\mathrm{pH}$ values of $<4.5$ to 5 , above which the solubility decreases to $<0.5 \mathrm{mg} / \mathrm{mL}$ due to its amphoteric nature. In a clinical study in which ranitidine 


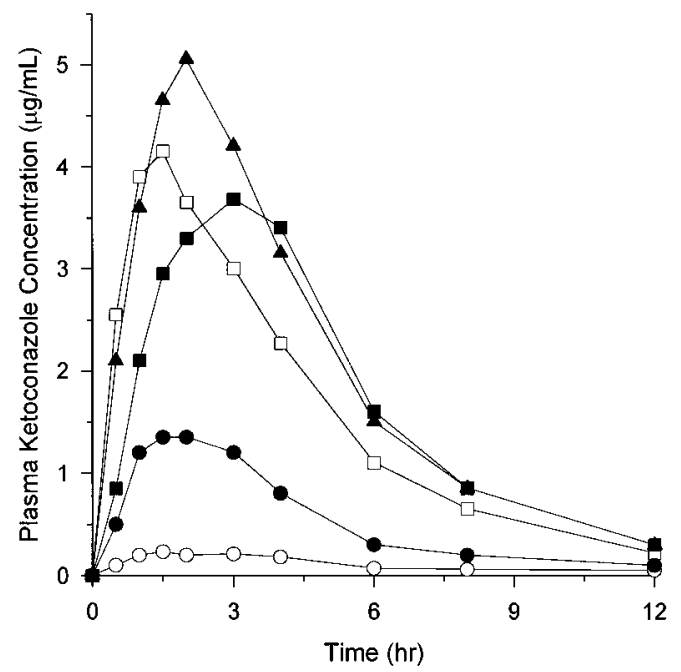

Figure 2-Mean plasma ketoconazole concentration versus time profiles after oral administration of $200 \mathrm{mg}$ of ketoconazole to subjects in either a fasted state

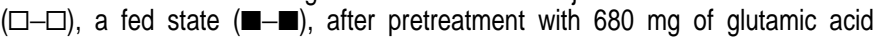
hydrochloride $(\boldsymbol{\Lambda}-\mathbf{\Delta})$, in a simulated achlorhydric state induced with cimetidine and bicarbonate $(\mathrm{O}-\mathrm{O})$, or after pretreatment with $680 \mathrm{mg}$ of glutamic acid hydrochloride in the simulated achlorhydric state (-). (Adapted from ref 217).

was administered to increase gastric $\mathrm{pH}$ above 5, the observed decrease in bioavailability may have been due to the decreased solubility of enoxacin at higher pH values.

Cefpodoxime proxetil is an oral cephem antibiotic that also exhibits pH-dependent dissolution. For example, the solubility of cefpodoxime proxetil in aqueous solutions is reduced from $\sim 11 \mathrm{mg} / \mathrm{mL}$ at acidic $\mathrm{pH}$ to $\sim 0.4 \mathrm{mg} / \mathrm{mL}$ at near neutral $\mathrm{pH}$. When subjects were treated with $40 \mathrm{mg}$ of famotidine 1 $\mathrm{h}$ prior to administration of cefpodoxime proxetil, the mean peak plasma levels were reduced by $48 \%$ from 2.5 to $1.3 \mu \mathrm{g} /$ $\mathrm{mL}$, and there was a similar decrease in the plasma AUC values from 14.0 to $8.4 \mu \mathrm{g} \mathrm{h} / \mathrm{mL} .220$

Diazepam is an example of a drug for which the rate, rather than the extent of absorption is affected by gastric $\mathrm{pH}$. Diazepam is a weak base with solubilities of $13.4 \mathrm{mg} / \mathrm{mL}$ at $\mathrm{pH} 1$ and $50 \mu \mathrm{g} / \mathrm{mL}$ at $\mathrm{pH}$ 7. In a clinical study conducted in healthy subjects, the maximum plasma concentration of diazepam was reduced by $50 \%$ in subjects with high gastric $\mathrm{pH}$ values compared with those with a low gastric $\mathrm{pH}$, although there was not a corresponding decrease in the plasma AUC values. ${ }^{221}$

Dipyridamole $\left(\mathrm{pK}_{\mathrm{a}} 6.4\right)$ has an aqueous solubility of $5 \mu \mathrm{g} /$ $\mathrm{mL}$ at $\mathrm{pH} 7.0$ that increases to $29 \mathrm{mg} / \mathrm{mL}$ at $\mathrm{pH}$ 2.5. Russell et al. ${ }^{222}$ found that when famotidine was administered concomitantly with dipyridamole to el evate gastric $\mathrm{pH}$ above 5.0, the plasma $\mathrm{C}_{\max }$ of dipyridamole was reduced by $79 \%$ when compared to control and the mean plasma $A \cup C^{0-36} \mathrm{~h}$ values were reduced by $37 \%$.

The absorption of inorganic salts are also sensitive to GI $\mathrm{pH}$ profiles. For example, calcium salts, which are often used in the treatment of osteoporosis in elderly women, are relatively insoluble and depend on an acidic $\mathrm{pH}$ for dissolution. Recker $^{223}$ found that the average fractional absorption of calcium, from a dose of calcium carbonate, was 0.047 in achlorhydric subjects compared with 0.225 in control subjects. The absorption of several trace elements, such as iron, zinc, and copper, also appears to depend on gastric acid for complete dissolution. ${ }^{184}$ Henderson et al. ${ }^{224}$ found that the mean plasma zinc AUC values from a dose of zinc acetate was reduced from $524 \mu \mathrm{g} \mathrm{h} / \mathrm{dL}$ in subjects with low gastric $\mathrm{pH}(\mathrm{pH}$ $<3$ ) to $378 \mu \mathrm{g} \mathrm{h} / \mathrm{dL}$ when $40 \mathrm{mg}$ of famotidine was administered prior to zinc administration, which maintained gastric $\mathrm{pH}$ above 5.0. When administered as zinc oxide, the zinc

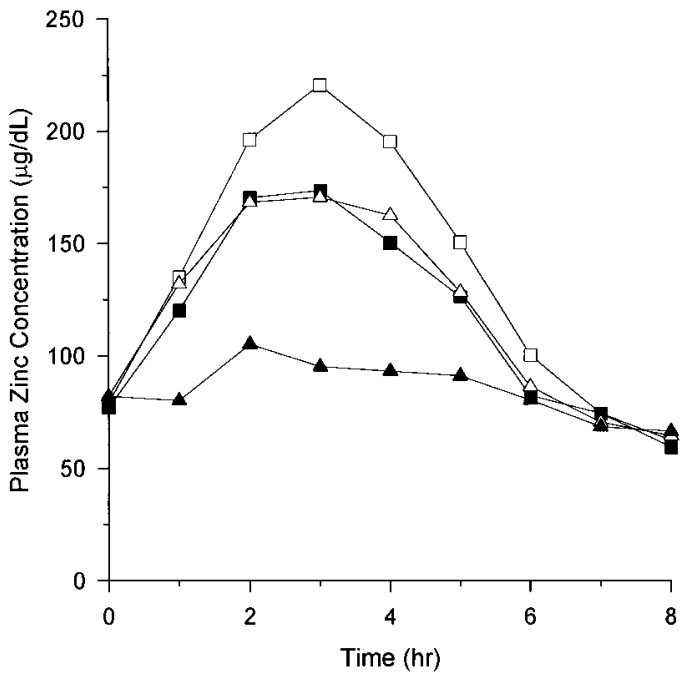

Figure 3-Plasma concentrations of zinc after administration of zinc acetate to subjects with low gastric $\mathrm{pH}(\square-\square)$ or high gastric $\mathrm{pH}(\mathbf{\square}-\mathbf{\square})$, and after administration of zinc oxide to subjects with low gastric $\mathrm{pH}(\Delta-\Delta)$ or high gastric $\mathrm{pH}(\boldsymbol{\Delta}-\boldsymbol{\Delta})$, in a crossover study conducted in fasted healthy subjects. (Adapted from ref 224).

plasma AUC was reduced $82 \%$ in subjects with elevated gastric $\mathrm{pH}$. The effect of gastric $\mathrm{pH}$ on the resulting plasma concentrations of zinc after administration of either zinc acetate or zinc oxide to subjects with low or high gastric pH is shown in Figure 3. In vitro studies verified the importance of a low $\mathrm{pH}$ value for facilitating the dissolution of these different zinc salts.

From the studies just described, gastric pH appears to be a primary determinant of absorption when drug dissolution is $\mathrm{pH}$ dependent and the solubility of the drug at higher $\mathrm{pH}$ values is poor. As described, the $\mathrm{pH}$ of gastric fluids is typically elevated above 3 (and to values as high as 5), during the first 60-90 min after ingestion of a meal. Consequently, if a poorly water-soluble, weakly basic drug is administered postprandially, dissolution in the stomach may be decreased and its subsequent absorption impaired due to periods of elevated gastric $\mathrm{pH}$. However, if the particular drug is relatively lipophilic, these potentially limiting effects of $\mathrm{pH}$ may be offset by bile-mediated dissolution and increased residence time in the upper $\mathrm{Gl}$ tract.

\section{Predictive Approaches to Assessing pH-Dependent Bioavailability}

Dissolution tests are a simple and ready means for characterizing the $\mathrm{pH}$-dependency of drug release and dissolution. In vitro dissolution tests should be conducted over the range of $\mathrm{pH}$ values that encompass the different $\mathrm{Gl} \mathrm{pH}$ profiles typically observed in fasted and fed states. Confirmatory dinical studies are often conducted if the solubility and dissolution profile of a drug indicates that postprandial absorption and bioavailability may be sensitive to the anticipated changes in $\mathrm{Gl} \mathrm{pH}$ values.

Clinical Studies-Clinical studies in humans offer a useful means to investigate the effect of gastric $\mathrm{pH}$ on drug absorption with either $\mathrm{H}_{2}$-receptor antagonists, proton pump inhibitors, or antacids to raise gastric $\mathrm{pH}$. Oral or intravenous cimetidine can effectively lower basal gastric acid secretion for periods of at least $5 \mathrm{~h}, 225,226$ and meal-stimulated secretion of acid for periods of 3 to $4 \mathrm{~h}$ in healthy subjects. 227,228 However, a drawback associated with the use of cimetidine to diagnostically evaluate the effect of gastric pH on bioavailability is its potential to inhibit the oxidative metabolism of 
some drugs via interaction with the cytochrome P-450 system. ${ }^{229-231}$ Ranitidine is $\sim 10-12$ times more potent than cimetidine in inhibiting gastric acid secretion in humans, 232,233 but famotidine is reported to be 20 times more potent than cimetidine on a molar basis. ${ }^{234}$ An oral dose of $300 \mathrm{mg}$ of ranitidine is sufficient to increase $24 \mathrm{~h}$ median gastric $\mathrm{pH}$ values from 1.3 to 4.0 in humans, 235 and produce an overall $70 \%$ reduction in acid secretion. ${ }^{236}$ Oral administration of a suspension of $40 \mathrm{mg}$ of famotidine can elevate gastric $\mathrm{pH}$ above 5.0 for at least $2-3 \mathrm{~h}$ after administration. ${ }^{224}$ In terms of effects on cytochrome $\mathrm{P}-450$, ranitidine is reported to be much less active than cimetidine, ${ }^{237,238}$ although famotidine does not appear to have any effect at therapeutic doses.239,240 However, ranitidine has been reported to either accelerate, ${ }^{241-243}$ have no effect, ${ }^{244,245}$ or delay gastric emptying in humans. 246,247 Cimetidine ${ }^{241,246,247}$ and famotidine 243,248 have no effect on the rate of gastric emptying in humans. Proton pump inhibitors, such as omeprazole and lansoprazole, can effectively el evate gastric $\mathrm{pH}$ above 4.0 on a round-the-clock basis. $249-251$ However, omeprazole has been reported to inhibit oxidative metabolism, ${ }^{252-254}$ but it has no effect on the rate of gastric emptying. 255,256

The use of antacids containing calcium, aluminum, or magnesium to study the effect of $\mathrm{pH}$ on absorption should be undertaken with caution because drugs such as tetracycline ${ }^{85,257}$ and the quinol one antibiotics ${ }^{258}$ form nonabsorbable chelates with the metal ions. Aluminum hydroxide gel has been found to del ay gastric emptying in humans. ${ }^{259,260}$ Sodium bicarbonate is often employed to neutralize gastric acidity as it does not form chelates with drugs and it has no effect on gastric emptying. ${ }^{261}$

The use of concomitant drug therapy to evaluate the effect of gastric $\mathrm{pH}$ on drug bioavailability is a well-accepted practice. However, care must be taken to ensure that the agent employed to modulate gastric $\mathrm{pH}$ does not alter other factors affecting drug bioavailability. Whenever these studies are undertaken, gastric $\mathrm{pH}$ should be continuously monitored in control and treated subjects because intragastric pH may fluctuate widely over time, and there is inherent variability in individual responses to proton pump inhibitors and $\mathrm{H}_{2}$ receptor antagonists. 262,263

\section{Conclusions and Perspectives}

The effect of food on the absorption of coadministered drugs has often been assessed in a largely phenomenological manner. The combined effects of slowed gastric emptying and the potential for binding to food components has typically been assumed to reduce, or at least slow drug absorption. In many cases, and particularly for water-soluble drugs with high bioavailability, this is indeed the situation. However, for drugs with either $\mathrm{pH}$-dependent solubility or poor aqueous solubility, postprandial alterations in $\mathrm{Gl} \mathrm{pH}$ and the enhanced solubilizing capacity of the Gl tract have the potential to significantly impact on drug absorption.

Changes in postprandial gastric physiology are primarily defined by a slowing of gastric emptying and a marked rise in $\mathrm{pH}$. These effects impact primarily on gastric dissolution, with the magnitude of effect being dependent on the $\mathrm{pK}_{a}$ and solubility of the drug. The transient rise in gastric $\mathrm{pH}$ is of most importance when assessing the postprandial dissolution of weak bases.

In the small intestine, coadministration of food and/or lipids leads to secretion of bile and digestive enzymes that produce a complex system of intestinal colloidal phases designed to facilitate the digestion and absorption of dietary lipids. The increased concentration of bile and the presence of bile salt/ dietary lipid mixed micelles can improve the wetting of poorly soluble drugs and increase their effective solubility via solubilization. Postprandial absorption may be improved by direct permeability enhancement due to FA and MG, or by solubilization that facilitates transport of lipophilic drugs across the aqueous diffusion layer. Intestinal lymphatic transport may also contribute to the absorption of highly lipophilic drugs.

Appreciation of the physicochemical basis for enhanced postprandial bioavailability can be prospectively used to design and optimize drug formulations and dosing strategies. Drugs or dosage forms that show poor dissolution or release rates at higher $\mathrm{pH}$ values should be administered in the fasted state. If it is necessary to administer such drugs in the fed state (e.g., those which cause gastric irritation in the fasted state), then they could be coadministered with drinks such as fruit juices or carbonated beverages that buffer gastric $\mathrm{pH}$ to lower values. Because of the inherent variability associated with gastric $\mathrm{pH}$ in the preprandial state, consideration could also be given to coadministration of a suitable drink with drugs for which dissolution is highly $\mathrm{pH}$ dependent.

Two variables affecting dissolution that can be controlled by formulation are surface area and solubility. For example, particle size can be reduced to increase the effective surface area available for dissolution, and the solubility of weak acids or bases can be modified by buffering the surrounding "microenvironment". However, use of buffering agents is often limited by differences in solubility between the buffer and the drug such that their relative rates of dissolution preclude maintenance of the microenvironment during the period of dissolution.

The challenge is to identify the potential physicochemical basis for food-enhanced bi oavailability of particular drugs and use it as a starting point to prospectively develop better oral formulations.

\section{References and Notes}

1. Welling, P. G. J . Pharmacokinet. Biopharm. 1977, 5, 291-334. 2. Pierpaoli, P. G. Clin. Pharm. 1972, 6, 89-99.

3. Welling, P. G.; Huang, H.; Kock, P. A.; Craig, W. A.; Madsen, P. O. J. Pharm. Sci. 1977, 66, 549-552.

4. McCracken, G. H.; Ginsburg, C. M.; Clahsen, J . C.; Thomas, M. L. Pediatrics 1978, 62, 738-743.

5. Willis, J. V.; J ack, D. B.; Kendall, M. J .; J ohn, V. A. Eur. J . Clin. Pharmacol. 1981, 19, 39-44.

6. Willis, J . V.; Kendall, M.J .; J ack, D. B. Eur. J . Clin. Pharmacol. 1981, 19, 33-37.

7. Melander, A.; Danielson, K.; Schersten, B.; Wahlin, E. Clin. Pharmacol. Ther. 1977, 22, 108-112.

8. Melander, A. Clin. Pharmacokinet. 1978, 3, 337-351.

9. Olanoff, L. S.; Walle, T.; Cowart, T. D.; Walle, W. K.; Oexmann, M. J .; Conradi, E. C. Clin. Pharmacol. Ther. 1986, 40, 408414.

10. Gupta, S. K.; Benet, L. Z. Pharm. Res. 1990, 7, 46-48.

11. Humberstone, A. J .; Porter, C. J . H.; Edwards, G. A.; Charman, W. N. Pharm. Res. 1995, 12, S-356.

12. Wagner, J. G. Hosp. Practice 1977, 12, 119-127.

13. Welling, P. G. Postgrad. Med. 1977, 62, 73-82.

14. Melander, A. Wld. Rev. Nutr. Diet, 1984, 43, 34-44.

15. Welling, P. G. Clin. Pharmacokinet. 1984, 9, 404-434.

16. Welling, P. G. Pharmacol. Ther. 1989, 43, 425-44.

17. Griffin, J. P. Pharmacol. Ther. 1981, 15, 79-88.

18. Walter-Sack, I. Klin. Wochenschr. 1987, 65, 927-935.

19. Sinko, P. J .; Leesman, G. D.; Amidon, G. L. Pharm. Res. 1991, 8, 979-988.

20. Oh, D.-M.; Curl, R. L.; Amidon, G. L. Pharm. Res. 1993, 10, 264270.

21. Amidon, G. L.; Lennernas, H.; Shah, V. P.; Crison, J . R. Pharm. Res. 1995, 12, 413-420.

22. Shiau, Y.-F. Am. J . Physiol. 1981, 240, G1-G9.

23. Bisgaier, C. L.; Glickman, R. M. Annu. Rev. Physiol. 1983, 45, 625-636.

24. Kuksis, A. In Fat Absorption; CRC: Boca Raton, FL, 1987.

25. Thomson, A. B. R.; Keelan, M.; Garg, M. L.; Clandinin, M. T. Can. J. Physiol. Pharmacol. 1989, 67, 179-191.

26. Tso, P. In Physiology of the Gastrointestinal Tract, 3rd ed. J ohnson, L. R., Ed.; Raven: New York, 1994; pp 1867-1907. 
27. Carey, M. C.; Small, D. M.; Bliss, C. M. Annu. Rev. Physiol. 1983, $45,651-677$

28. Hoffman, A. F. Gastroenterology 1978, 75, 530-532.

29. Borgstrom, B.; Erlanson-Albertsson, C.; Wieloch, T. J . Lipid Res. 1979, 20, 805-816.

30. Borgstrom, B. Gastroenterology 1980, 78, 954-962.

31. Bernback, S.; Blackberg, L.; Hernell, O. Biochim. Biophys. Acta 1989, 1001, 286-293.

32. Hofmann, A. F.; Borgstrom, B. Fed. Proc. 1962, 21, 43-50.

33. Hofmann, A. F.; Borgstrom, B. J . Clin. Invest. 1964, 43, 247257.

34. Staggers, J. E.; Hernell, O.; Stafford, R. J ; Carey, M. C. Biochemistry 1990, 29, 2028-2040.

35. Hernell, O.; Staggers, J. E.; Carey, M. C. Biochemistry 1990, 29, 2041-2056.

36. Dietschy, J. M.; Sallee, V. L.; Wilson, F. A. Gastroenterology 1971, 61, 932-934.

37. Westergaard, H.; Dietschy, J . M. J . Clin. Invest. 1976, 58, 97108.

38. Wilson, F. A.; Sallee, V. L.; Dietschy, J . M. Science 1971, 174, 1031-1033.

39. Hoffman, N. E. Biochim. Biophys. Acta 1970, 196, 193-203.

40. Simmonds, W. J. Aust. J . Exp. Biol. Med. Sci. 1972, 50, 403421.

41. Chijiiwa, K.; Nagai, M. Arch. Biochem. Biophys. 1989, 270, 472477.

42. Chijiiwa, K.; Nagai, M. Biochim. Biophys. Acta 1989, 1001, 111114.

43. Lucas, M. L.; Schneider, W.; Haberich, F. J .; Blair, J . A. Proc. Royal Soc. B 1975, 192, 39-48.

44. Shiau, Y.-F.; Fernandez, P.; J ackson, M.J .; McMonagle, S. Am. J. Physiol. 1985, 248, G608-619.

45. Shiau, Y.-F.J. Physiol. 1990, 421, 463-474.

46. Stremmel, W.; Lotz, G.; Strohmeyer, G.; Berk, P. D. J . Clin. Invest. 1985, 75, 1068-1075.

47. Stremmel, W. J . Clin. Invest. 1988, 82, 2001-2010.

48. Davidson, N. O. In Physiology of the Gastrointestinal Tract, 3rd ed.; J ohnson, L. R., Ed.; Raven: New York, 1994; pp 1909-1934.

49. Kiyasu, J. Y.; Bloom, B.; Chaikoff, I. L. J . Biol. Chem. 1952, $199,415-419$.

50. McDonald, G. B.; Saunders, D. R.; Weidman, M.; Fisher, L. Am. J . Physiol. 1980, 239, G141-G150.

51. McDonald, B.; Weidman, M. Quart. J . Exp. Physiol. 1987, 72, 153-159.

52. I saksson, B. Acta. Soc. Med. U psal. 1951, 56, 177-195.

53. Rautureau, M.; Bisalli, A.; Rimbaud, J . Clin. Biol. 1981, 5, 417425.

54. Westergaard, H. Scand. J. Gastroenterol. 1977, 12, 115-122.

55. Carey, M. C.; Small, D. M. Am. J . Med. 1970, 49, 590-608.

56. Carey, M. C.; Small, D. M. Arch. Intern. Med. 1972, 130, 506527.

57. Carey, M. C.; Small, D. M. J . Colloid Interface Sci. 1969, 31, 382.

58. Bakatselou, V.; Oppenheim, R. C.; Dressman, J . B. Pharm. Res. 1991, 8, 1461-1469.

59. Naylor, L. J .; Bakatsel ou, V.; Dressman, J . B. Pharm. Res., 1993, $10,865-870$

60. Higuchi, W. I.; Parrot, E. I.; Wuster, D.; Higuchi, T. J . Am. Pharm. Assoc. Sci. Ed. 1958, 47, 376-383.

61. Bates, T. R.; Gibaldi, M.; Kanig, J . L. Nature 1966, 210, 13311332.

62. Bates, T. R.; Gibaldi, M.; Kanig, J . L. J . Pharm. Sci. 1966, 55, 191-199.

63. Bates, T. R.; Gibaldi, M.; Kanig, J . L. J . Pharm. Sci. 1966, 55, 901-906.

64. Kassem, M. A.; Mattha, A. G.; El-Nimr, A. E. M.; Omar, S. M. Int. J. Pharm. 1982, 12, 1-9.

65. Mattha, A. G.; Omar, S. M.; Kassem, M. A. Int. J . Pharm. 1982, $11,27-34$.

66. Rosoff, M.; Serajuddin, A. T. M. Int. J . Pharm. 1980, 6, 137146

67. Humberstone, A.J .; Porter, C. J . H.; Charman, W. N. J . Pharm. Sci. 1966, 85, 525-529.

68. Kararli, T. T.; Gupta, V. W. J . Pharm. Sci. 1992, 81, 483-485.

69. Luner, P. E.; Babu, S. R.; Radebaugh, G. W. Pharm. Res. 1994, $11,1755-1760$.

70. Miyazaki, S.; Inoue, H.; Yamahira, T.; Nadai, T. Chem. Pharm. Bull. 1979, 27, 2468-2472.

71. Miyazaki, S.; Yamahira, T.; I noue, H.; Nadai, T. Chem. Pharm. Bull. 1980, 28, 323-326.

72. Miyazaki, S.; Yamahira, T.; Morimoto, Y.; Nadui, T. Int. J. Pharm. 1981, 8, 303-310.

73. Higuchi, W. I.; Prakongpan, S.; Surpuriya, V.; Young, F. Science 1972, 178, 633-634.

74. Higuchi, W. I.; Sjuib, F.; Mufson, D.; Simonelli, A. P.; Hofmann, A. F. J . Pharm. Sci. 1973, 62, 942-945.
75. Higuchi, W. I.; Prakongpan, S.; Young, F. J . Pharm. Sci. 1973, 62, 1207-1208

76. Higuchi, W. I.; Prakongpan, S.; Young, F. J . Pharm. Sci. 1973, $62,945-948$

77. Prakongpan, S.; Higuchi, W. I.; Kwan, K. H.; Molokhia, A. M. J. Pharm. Sci. 1976, 65, 685-689

78. Molokhia, A. M.; Hofmann, A. F.; Higuchi, W. I. Truchinda, M.; Feld, K.; Prakongpan, S.; Danzinger, R. G. J . Pharm. Sci. 1977, 66, 1101-1105.

79. Kwan, K. H.; Higuchi, W. I.; Molokhia, A. M.; Hofmann, A. F. J. Phys. Sci. 1977, 66, 1094-1101.

80. Gupta, S. L.; Higuchi, W. I.; Ho, N. F. H. J . Pharm. Sci. 1985, 74, 1178-1183.

81. Lennernas, H.; Regardh, C.-G. Pharm. Res. 1993, 10, 879-883.

82. Mahfouz, M. Br. J. Pharmacol. 1949, 4, 295-303.

83. Faloon, W. W.; Paes, I. C.; Woolfolk, D.; Nanken, H.; Wallace, K.; Haro, E. N. Ann. N.Y. Acad. Sci. 1966, 32, 879-887.

84. Schneierson, S. S.; Amsterdam, D. Nature 1958, 182, 56-57.

85. Neuvonuen, P.J .; Gothini, G.; Hackman, R.; Bjorksten, K. Br. Med. J . 1970, 4, 532-534

86. Schuna, A.; Osman, M. A.; Patel, R. B.; Welling, P. G.; Sundstrom, W. P. J . Rheumatol. 1983, 10, 95-97.

87. Gibaldi, M.; Feldman, S. J . Pharm. Sci. 1970, 59, 579-589.

88. Kajii, H.; Horie, T.; Hayashi, M.; Awazu, S. J. Pharm. Sci. 1988, 77, 390-392

89. Yamashita, S.; Masada, M.; Nadai, T.; Kumura, T. J . Pharm. Sci. 1990, 79, 579-583.

90. Anderberg, E. K.; Lindmark, T.; Artursson, P. Pharm. Res. 1993, $10,857-864$.

91. Aungst, B. J. J . Pharm. Sci. 1993, 82, 979-987.

92. Muranishi, S.; Y amamoto, A. In Drug Ábsorption Enhancement; de Boer, A. G., Ed.; Harwood Academic: Switzerland, 1994; pp 67-100.

93. Swenson, E. S.; Milisen, W. B.; Curatolo, W. Pharm. Res. 1994, $11,1132-1142$

94. Curatolo, W.; Ochoa, R. In Drug Absorption Enhancement; de Boer, A. G., Ed.; Harwood Academic: Switzerland, 1994; pp 367-389.

95. Kvietys, P. R.; Speian, R. D., Grisham, M. B.; Tso, P. Am. Physiol. 1991, 261, G384-G391.

96. Poelma, F. G. J .; Tukker, J . J .; Crommelin, D. J . A. J . Pharm. Sci. 1989, 78, 285-289.

97. Poelma, F. G. J .; Breas, R.; Tukker, J J J . Pharm. Res. 1990, 7, 392-397.

98. Segura-Bono, M. J .; Garrigues, T. M.; Merino, V.; Bermejo, M. V. Int. J. Pharm. 1994, 107, 159-166.

99. Pla-Delfina, J. M.; Perez Buendia, M. D.; Casabo, V. G.; PerisRibera, J. E.; Sanches-M oyano, E.; Martin-Villodre, A. M. Int. J. Pharm. 1987, 37, 49-64.

100. Collado, E. F.; Fabra-Campos, S.; Peris-Ribera, J . E.; Casabo, V. G.; Martin-Villodre, A.; Pla-Delfina, J . M. Int. J . Pharm. 1988, $44,187-196$

101. Bermejo, M. V.; Perez-Varona, A. T.; Segura-Bono, M.J .; MartinVillodre, A.; Pla-Delfina, J. M.; Garrigues, T. M. Int. J . Pharm. 1991, 69, 221-231.

102. Garrigues, T. M.; Segura-Bono, M. J .; Bermejo, M. V.; Merino, V.; Pla-Delfina, J. M. Int. J . Pharm. 1994, 101, 209-217.

103. O'Reilly, J . R.; Corrigan, O. I.; O'Driscoll, C. M. Int. J . Pharm. 1994, 105, 137-146.

104. O'Reilly, J. R.; Corrigan, O. I.; O'Driscoll, C. M. Int. J . Pharm. 1994, 109, 147-154.

105. Katz, K. D.; Hollander, D. Ballieres Clin. Rheumatol. 1989, 3, $271-284$

106. Muranishi, S.; Muranushi, N.; Sezaki, H. Int. J . Pharm. 1979, 2, 101-111.

107. Muranushi, N.; Nakajima, Y.; Kinugawa, M.; Muranishi, S.; Sezaki, H. Int. J. Pharm. 1980, 4, 281-290.

108. Muranushi, N.; Kinugawa, M.; Nakajima, Y.; Muranishi, S.; Sezaki, H. Int. J. Pharm. 1980, 4, 271-279.

109. Hunt, j. N.; Knox, M. T. J . Physiol. 1968, 194, 327-336.

110. Hunt, ] . N.; Knox, M. T. In Handbood of Physiology, Section 6 Alimentary Canal; Code, C. F., Ed.; Williams and Wilkins: Baltimore; 1972; pp 1917-1935.

111. Davis, S. S.; Hardy, J . G.; Fara, J . W. Gut 1986, 27, 886-892.

112. Khosla, R.; Feely, L. C.; Davis, S. S. Int. J. Pharm. 1989, 53, 107-117.

113. Khosla, R., Davis, S. S. Int. J . Pharm. 1989, 52, 1-10.

114. Wilson, C. G.; Washington, N. In Physiological Pharmaceutics; Wilson, C. G.; Washington, N., Eds.; Ellis Horwood: Chichester, U.K., 1989; pp 47-70.

115. Follonier, N.; Doelker, E. S.T.P. Pharma. Sci. 1992, 2, 141158.

116. Charman, W. N.; Stella, V. J. Adv. Drug. Deliv. Rev. 1991, 7, $1-14$.

117. Lymphatic Transport of Drugs; Charman, W. N.; Stella, V. J Eds.; CRC: Boca Raton, FL, 1992. 
118. Charman, W. N.; Porter, C. J . H. Adv. Drug. Del. Rev. 1996, 19, $149-169$.

119. Porter, C. J . H.; Charman, W. N. Adv. Drug. Del. Rev., in press.

120. Ueda, C. T.; Lemaire, M.; Gsell, G.; Nussbaumer, K. Biopharm. Drug. Dispos. 1983, 4, 113-124.

121. Grimus, R. C.; Schuster, I. Xenobiotica 1984, 14, 287-294.

122. Palin, K. J .; Wilson, C. J . J . Pharm. Pharmacol. 1984, 36, 641643.

123. Ichihashi, T.; Kinoshita, H.; Takagishi, Y.; Yamada, H. J . Pharm. Pharmacol. 1992, 44, 560-564.

124. Ichihashi, T.; Kinoshita, H.; Takagishi, Y.; Yamada, H. J. Pharm. Pharmacol. 1992, 44, 566-569.

125. Kuksis, A. In F at Absorption; Kuksis, A., Ed.; CRC: Boca Raton, FL, 1987; Vol. 2, Chapter 3.

126. Porter, C. J . H.; Charman, S. A.; Charman, W. N. J . Pharm. Sci. 1996, 85, 351-356.

127. Sieber, S. M. Pharmacology 1976, 14, 443-454.

128. Charman, W. N.; Noguchi, T.; Stella, V. J . Int. J . Pharm. 1986, 33, 155-164.

129. Charman, W. N.; Stella, V. J . Int. J . Pharm. 1986, 33, 165172.

130. Laher, J . M.; Rigler, M. W.; Vetter, R. D.; Barrowman, J . A.; Patton, J. S. J . Lipid Res. 1984, 25, 1337-1342.

131. Zilvermist, D. B. J. Clin. Invest. 1965, 44, 1610-1622.

132. Charman, W. N. In Lymphatic Transport of Drugs; Charman, W. N.; Stella, V. J ., Eds.; CRC: Boca Raton, FL, 1992; pp 113179.

133. Charman, W. N.; Stella, V. J . Int. J . Pharm. 1986, 34, 175178.

134. Raub, T. J .; Douglas, S. L.; Melchior, G. W.; Charman, W. N.; Morozowich, W. In Lymphatic Transport of Drugs; Charman, W. N.; Stella, V. J ., Eds.; CRC: Boca Raton, FL, 1992; pp 63112.

135. Crounse, R. G. J . Invest. Dermatol. 1961, 37, 529-532.

136. DeSmidt, J . H.; Grit, M.; Crommelin, D. J . A. J . Pharm. Sci. 1994, 83, 1209-1212.

137. Charman, W. N.; Rogge, M. C.; Boddy, A. W.; Berger, B. M. J . Clin. Pharmacol. 1993, 33, 381-386.

138. Naylor, L. J .; Bakatselou, V.; Rodriguez-Homedo, N.; Weiner, N. D.; Dressman, J . B. Eur. J . Pharm. Biopharm. 1995, 41, 346353.

139. Gallo-Torres, H. E. Lipids 1970, 5, 379-384.

140. Hasegawa, J ; Tomono, Y.; Fujita, T.; Sugiyama, K.; Hamamura, K. Int. J. Clin. Pharmacol. Ther. Toxicol. 1981, 19, 216-219.

141. Fukui, E.; Kurohara, H.; Kareyu, A.; Kurisaki, Y.; Nakayaman, T.; Kimura, T. J. Pharmacobio-Dyn. 1989, 12, 80-86.

142. Kimura, T.; Fukui, E.; Kageyu, A.; Kurohara, H.; Kurosaki, Y.; Nakayama, T.; Morita, Y.; Shibusawa, K.; Ohsawa, S.; Takeda, Y. Chem. Pharm. Bull. 1989, 37, 439-41.

143. Milton, K. A.; Edwards, G.; Ward, S. A.; Orme, M. L.'E.; Breckenridge, A. M. Br. J . Clin. Pharmacol. 1989, 28, 71-77.

144. Porter, C.J.H.; Charman, S. A.; Humberstone, A. J .; Charman, W. N.J. Pharm. Sci. 1996, 85, 357-361.

145. Rolan, P. E.; Mercer, A.J .; Weatherley, B. C.; Holdich, T.; Meire, H.; Peck, R. W.; Ridout, G.; Posner, J . Br. J . Clin. Pharmacol. $1994,37,13-20$.

146. Colburn, W. A.; Gibson, D. M.; Rodriguez, L. C.; Bugge, C. J. L.; Blumenthal, H. P. J . Clin. Pharmacol. 1985, 25, 583-589.

147. DiGiovanna, J . J .; Gross, E. G.; McClean, S. W.; Ruddel, M. E.; Gantt, G.; Peck, G. L. J . Invest. Dermatol. 1984, 82, 636-640.

148. Colburn, W. A.; Gibson, D. M.; Wiens, R. E.; Hanigan, J . J . J . Clin. Pharmacol. 1983, 23, 534-539.

149. Mithani, S.; Bakatselou, V.; Tenhoor, C. N.; Dressman, J. B. Pharm. Res. 1996, 13, 163-167.

150. Wu, C. Y.; Benet, L. Z.; Hebert, M. F.; Gupta, S. K.; Rowland, M.; Gomez, D. Y.; Wacher, V. J. Clin.' Pharm. Ther. 1995, 58, $492-497$.

151. Benet, L. Z.; Wu, C. Y.; Hebert, M. F .; Wacher, V. J . J . Controlled Release 1996, 39, 139-143.

152. Chang, T.; Benet, L. Z.; Hebert, M. F. Clin. Pharm. Ther. 1996, 59, 297-303.

153. Nerurkar, M. M.; Burton, P. S.; Borchardt, R. T. Pharm. Res. 1996, 13, 528-534.

154. Gargouri, Y.; Pieroni, G.; Riviere, C.; Lowe, P. A.; Sauniere, J .F.; Sarda, L.; Verger, R. Biochim. Biophys. Acta 1986, 879, 419423.

155. Lindstrom, M. B.; Sternby, B.; Borgstrom, B. Biochim. Biophys. Acta 1988, 959, 178-184.

156. Reymond, J.-P.; Sucker, H. Pharm. Res. 1988, 5, 673-676.

157. Porter, C. J. H.; Charman, W. N. In Models for Assessing Drug Absorption and Metabolism; Borchardt, R. T.; Smith, P. L.; Wilson, G., Eds.; Plenum: New York, 1996; pp 85-102.

158. J ohnson, L. R. In Gastrointestinal Physiology; J ohnson, L. R., Ed.; Mosby Year Book: St. Louis, MO, 1991; pp 223-225.

159. Davenport, H. W. In Physi ol ogy of the Digestive Tract, 3rd ed.; Yearbook Medical Publishers: Chicago, 1984; p 125.
160. Feldman, M.; Barnett, C. Dig. Dis. Sci, 1991, 36, 866-869.

161. Debas, H. T.; Grossman, M. I. Digestion 1973, 9, 469-481.

162. Vantrappen, G. R.; Peeters, T. L.; J anssens, J . Scand. Gastroenterol. 1979, 14, 663-667.

163. Kean, F. B.; DiMagno, E. P.; Malagelada, J . R. Gastroenterology 1981, 81, 726-731.

164. Owyang, C.; Achem-Karam, S. R.; Vinik, A. I. Gastroenterology 1983, 84, 10-17.

165. Zimmerman, M.J .; J anowitz, H. D. In The Exocrine Pancreas: Biology, Pathol ogy and Disease; Go, V. L. W.; Gardner, J. D.; Brooks, F. P.; Lebenthal, E.; DiMagno, E. P.; Scheele, G., Eds.; Raven: New York, 1986; p 275.

166. Dreiling, D. A.; J anowitz, H. D. Gastroenterology 1956, 30, 382386.

167. Malagelada, J . R.; Longstreth, G. F.; Summerskill, W. H. J .; Go, V. L. W. Gastroenterology 1976, 70, 203-210.

168. Bendsten, F.; Rune, S. J . Scand. J . Gastroenterol . 1988, 23, 935940.

169. Savarino, V.; Mela, G. S.; Scalabrini, P.; Sumbarez, A.; Celle, G. Dig. Dis. Sci. 1988, 9, 1077-1080.

170. Dressman, J. B.; Berardi, R. R.; Dermentzoglou, L. C.; Ressell, T. L.; Schmaltz, S. P.; Barnett, J . L.; J arvenpaa, K. M. Pharm. Res. 1990, 7, 756-751.

171. Rune, S. J .; Viskum, K. Gut 1969, 10, 569-571.

172. Hannibal, S.; Rune, S. J . Eur. J . Clin. Invest. 1983, 13, 455460.

173. McCloy, R.; Greenberg, G.; Baron, J. Gut 1984, 90, 386-392.
174. Ovesen, L.; Bendsten, F.; Tage-J ensen, U.; Pendersen, N.; Gram, B.; Rune, S. Gastroenterology 1986, 90, 958-962

175. Benn, A.; Cooke, W. T. Scand. J . Gastroenterol. 1971, 6, 313317.

176. Florence, A.; Atwood, D. In Physicochemical Principles of Pharmacy; Chapman and Hall: New York, 1988.

177. Watson, W. C.; Watt, J . K.; Paton, E.; Glen, A.; Lewis, G. J . T. Gut 1966, 7, 700-705.

178. Zentler-Munro, P.; Fitzpatrick, W.; Batten, J .; Northfield, T. Gut 1984, 25, 500-507.

179. Gruber, P.; Longer, M.; Robinson, J . Adv. Drug Del. Rev. 1987, $1,1-18$.

180. Gray, V. A.; Dressman, J. B. Pharm. Forum 1996, 22, 19431945.

181. Sievers, M. L. Am. J . Gastroenterol. 1966, 45, 99-108.

182. Christianen, P. M. Scand. J . Gastroenterol. 1968, 3, 497-508.

183. Varis, K.; Ihamaki, T.; Harkonen, M.; Samloff, I. M.; Siruala, M. Scand. J . Gastroenterol. 1979, 14, 129-139.

184. Holt, P. R.; Rosenberg, H.; Russell, R. M. Dig. Dis. Sci. 1989, 34, 933-937.

185. Russell, T. L.; Berardi, R. R.; Barnett, J . L.; Dermentzoglou, L. C.; J arvenpaa, K. M.; Schmaltz, S. P.; Dressman, J . B. Pharm. Res. 1993, 10, 187-196.

186. Lake-Bakaar, G.; Quadros, E.; Beidas, S.; Elaskr, M.; Tom, W.; Wilson, D.; Dinscoy, H. P.; Cohen, P.; Straus, E. W. Ann. Int. Med. 1988, 112, 502-504.

187. Schentag, J . J .; Thomas, T. F. Am. J . Hosp. Pharm. 1993, 50, S7-S11.

188. Fordtran, J. S.; Walsh, J. H. J . Clin. Invest. 1973, 52, 645-657.

189. Blair, A. J .; Feldman, M.; Barnett, C.; Walsh, J . H.; Richardson, C. T. Gastroenterology 1987, 79, 582-587.

190. Goldschmeidt, M.; Barnett, C.; Schwartz, B. E.; Karnes, W. E.; Redfern, J. S.; Feldman, M. Gastroenterol ogy 1991, 101, 977990.

191. Beglinger, C.; Fried, M.; Whitehouse, I.; Lamers, C. B.; Gyr, K. J. Clin. Invest. 1985, 75, 1471-1476.

192. Kararli, T. T. Crit. Rev. Ther. Drug Carrier Sys. 1989, 6, 3986.

193. Malagelada, J . R.; Go, V. L. W.; Deering, T.; Summerskill, W. Gastroenterol ogy 1977, 73, 989-994.

194. Youngberg, C. A.; Berardi, R. R.; Howatt, W. F.; Hynec, M. C.; Amidon, G. L.; Meyer, J . H.; Dressman, J.'B. Dig. Dis. Sci. 1987, $32,472-480$

195. Temple, J. G.; Birch, A.; Shields, R. Gut 1975, 16, 961-965.

196. Ogata, H.; Shibazaki, T.; Inoue, T.; Ejima, A. J . Pharm. Sci. 1979, 68, 712-715.

197. Ogata, H.; Aoyagi, N.; Kaniwa, N.; Shibazaki, T.; Ejima, A.; Takagishi, Y.; Ogura, T.; Tomita, K.; Inoue, S.; Zaizen, M. Int. J. Pharm. 1985, 23, 277-288.

198. Dresman, J. B. In Comprehensive Medicinal Chemistry; Hansch, C., Ed.; Pergamon: New York, 1990; Vol. 5, p 637.

199. Qureshi, S. A.; Caille, G.; Lacasse, Y.; McGilveray, J . Pharm. Res. 1994, 11, 1669-1672.

200. Ranade, V. V. J . Clin. Pharmacol. 1991, 31, 98-115

201. Kohri, N.; Miyata, N.; Takahashi, M.; Endo, H.; I seki, K.; Miyazaki, K.; Takechi, S.; Nomura, A. Int. J . Pharm. 1992, 81, 49-58.

202. Koparkar, A. D.; Augsberger, L. L.; Shangraw, R. F. Pharm. Res. 1990, 7, 80-86. 
203. Hollenbeck, R. G.; Mitrevej, K. T.; Fan, A. C. J . Pharm. Sci. 1983, 72, 325-327.

204. Hom, F. S.; Veresh, S. A.; Mickel, J . J . J . Pharm. Sci. 1973, 62, 1001-1006.

205. Cohen, A. F.; Kroon, R.; Schoemaker, R.; Hoogkamer, H.; van Vlient, A. Ann. Int. Med. 1991, 115, 540-545.

206. Shore, P. A.; Brodie, B. B.; Adrian, C.; Hogben, M. J . Pharmacol. Exp. Ther. 1957, 119, 361-369.

207. Winne, D. J . Pharmacokinet. Biopharm. 1977, 5, 53-94

208. Elliot, R. L.; Amidon, G. L.; Lightfoot, E. N.J . Theor. Biol. 1980, 87, 757-771.

209. Amidon, G. L.; Leesman, G. D.; Elliot, R. L. J . Pharm. Sci. 1980, 69, 1363-1368.

210. Dressman, J . B.; Fleisher, D.; Amidon, G. L. J . Pharm. Sci. 1984, 73, 1274-1279.

211. Lui, C. Y.; Amidon, G. L.; Berardi, R. R.; Fleisher, D.; Youngberg, C.; Dressman, J. B. J. Pharm. Sci. 1986, 75, 271-274.

212. Merfeld, A. E.; Mlodozeniec, A. R.; Cortese, M. A.; Rhodes, J. B.; Dressman, J . B.; Amidon, G. L. J . Pharm. Pharmacol. 1986, 38, 815-822.

213. Lu, S. H. Doctoral Dissertation, University of Michigan, 1991.

214. Carlson, J . A.; Mann, H. J .; Canafax, D. D. Am. J . Hosp. Pharm. 1983, 40, 1334-1336.

215. Piscitelli, S. C.; Goss, T. F.; Witon, J . H.; D'Andrea, D. T.; Goldstein, H.; Schentag, J . J . Antimi crob. Agents Chemother. 1991, 35, 1756-1771.

216. Blum, R. A.; D'Andrea, D. T.; Florentino, B. M.; Wilton, J . H.; Hilligoss, D. M.; Gardner, M. J .; Henry, E. B.; Goldstein, H.; Schentag, J . J . Ann. Int. Med. 1991, 114, 755-757.

217. Lelawongs, P.; Barone, J . A.; Colaizzi, J . L.; Hsuan, A. T. M.; Mechlinski, W.; Legendre, R.; Guarnieri, J . Clin. Pharm. 1988, 7, 228-235.

218. Ogata, H.; Aoyagi, N.; Kaniwa, N.; Ejima, A.; Sekini, N.; Kitamura, M.; I noue, Y. Int. J . Pharm. 1986, 29, 113-120.

219. Lebsack, M. E.; Nix, D.; Ryerson, B.; Toothaker, R. D.; Welage, L.; Norman, A. M.; Schentag, J. J .; Sedman, A. J. Clin. Pharmacol. Ther. 1992, 52, 252-256.

220. Saathoff, N.; Lode, H.; Neider, K.; Depperman, K. M.; Borner, K.; Koeppe, P. Antimicrob. Agents Chemother. 1992, 36, 796800.

221. Ogata, H.; Aoyagi, N.; Kaniwa, N.; Koibuchi, M.; Shibazaki, T.; Ejima, A. Int. J. Clin. Pharm. Ther. Toxicol. 1982, 20, 166170.

222. Russell, T. L.; Berardi, R. R.; Barnett, J . L.; O'Sullivan, T. L.; Wagner, J. G.; Dressman, J. B. Pharm. Res. 1994, 11, 136-143.

223. Recker, R. R. N. Engl. J. Med. 1985, 313, 70-73.

224. Henderson, L. M.; Brewer, G. J .; Dressman, J. B.; Swidan, S. Z.; DuRoss, D. J .; Adair, C. H.; Barnett, J . L.; Berardi, R. R. J . Parent. Ent. Nutrition 1995, 19, 393-397.

225. Henn, R. M.; Isenberg, J. I.; Maxwell, V.; Sturdevant, R. A. L. New Engl. J. Med. 1975, 293, 371-375

226. Domschke, W.; Domschke, S.; Reim, E. In Cimetidine; Greutzfeldt, W., Ed.; Exerpta Medica: Amsterdam, 1988; pp 81-85.

227. Richardson, C. T.; Walsh, J. H.; Hicks, M. I. Gastroenterology 1976, 71, 19-23.

228. Mosberg, S.; Carberger, G.; Gilliam, H.; Befritz, R. Scand. J . Gastroenterol. 1977, 12, 145-148.

229. Henry, D. A.; MacDonald, I. A.; Kitchingman, G.; Bell, G. D.; Langman, M. J. Br. Med. J . 1980, 281, 775-777.

230. Breen, K. J .; Bury, R.; Desmond, P. V.; Mashford, M. L.; Morphett, B.; Westwood, B.; Shaw, R. G. Clin. Pharmacol. Ther. 1982, 31, 297-300.

231. Pasanen, M.; Arvela, P.; Pelkonen, O.; Sotaniemi, E.; Klotz, U. Biochem. Pharmacol. 1986, 35, 4457-4461.

232. Konturek, S. J .; Obtulowicz, N.; Kopp, B.; Olesky, J . Scand. J . Gastroenterol.1981, 16, 91-95.
233. Walt, R. D. Male P. J. Rawlings, J .; Hunt, R. H. MiltonThompson, G. J .; Misiewicz, J . J . Gut 1981, 22, 49-53.

234. Dammann, H. G.; Muller, P.; Simon, B. Lancet 1983, 2, 1078.

235. Merki, H. S.; Witzel, L.; Kaufmann, D.; Kempf, M.; Mussig, V.; Meumann, J.; Scheurlle, E.; Rohmel, J .; Walt, R. P. Aliment. Pharmacol. Ther. 1988, 2, 73-81.

236. Davis, S. S.; Stockwell, A. F.; Taylor, M. J .; Hardy, J. G.; Whalley, D. R.; Wilson, C. G.; Bechgaard, H.; Christensen, F. N. Pharm. Res. 1986, 3, 208-211.

237. Mosca, P.; Freddara, U.; Lorenzini, I.; Venturini, C.; J ezequel, A. M.; Orlandi, F. Pharmacol. Res. Commun. 1985, 17, 513524.

238. Bast, A.; Smid, K.; Timmerman, H. Agents Action 1989, 27, 188191.

239. Staiger, C.; Korodnay, B.; Devries, J . X. J . Clin. Pharmacol. 1984, 18, 105-106

240. Somerville, K. W.; Kitchingman, G. A.; Langman, M. J . S. Eur. J . Clin. Pharmacol. 1986, 30, 279-281.

241. Scarpignato, C.; Bertaccini, G. Agents Action 1982, 12, 172173.

242. Mojaverian, P.; Vlassess, P. H.; Parker, S.; Warner, C. Clin. Pharmacol. Ther. 1990, 47, 382-388.

243. Ohira, Y.; Hanya, N.; Aoki, T.; Hashimoto, Y.; likura, M.; Fakuda, S. J . Smooth Muscle Res. 1993, 29, 131-142.

244. Corinaldesi, R.; Scarpignato, C.; Galassi, A.; Stanghellini, V.; Calamelli, R.; Bertaccini, G.; Barbara, L. Int. J . Clin. Pharmacol. Ther. Toxicol. 1984, 22, 498-501.

245. Dobrilla, G.; dePetris, G.; Comberlato, M.; Amplatz, S. Hepatogastrenterol ogy 1988, 35, 30-33.

246. J onderko, K. J. Clin. Gastroenterol. 1988, 10, 143-149.

247. Mushambi, M. C.; Trotter, T. N.; Barker, P.; Rowbotham, D. J . Br. J . Clin. Pharmacol. 1992, 34, 278-280.

248. Chremos, A. N. Am. J. Med. 1986, 81, 3-7.

249. Gin, T.; E wart, M. C.; Yau, G.; On, T. E. Br. J . Anaesth. 1990, 65, 616-619.

250. Walker, S.; Klotz, U.; Sarem-Aslani, A.; Treiber, G.; Bode, J . C. Digestion 1991, 48, 179-184.

251. Hongo, M.; Ohara, S.; Hirasawa, Y.; Abe, S.; Asaki, S.; Toyota, T. Dig. Dis. Sci. 1992, 37, 882-890.

252. Gugler, R.; J ensen, J . C. Gastroenterol ogy 1985, 89, 1235-1241.

253. Henry, D. A.; Gerkens, J . F.; Brent, P.J. Dosen, P. J . Clin. Exp. Pharmacol. Physiol. 1986, 13, 377-381.

254. Li, G.; Klotz, U. Arzneim-Forsch. 1990, 40, 1105-1107.

255. Horowitz, M.; Hetzel, D. J .; Buckle, P. J .; Chatterton, B. E.; Shearman, D. J. Br. J . Clin. Pharmacol. 1984, 18, 791-794.

256. Rasmussen, L.; Oster-j orgensen, E.; Qvist, N.; Kraglund, K.; Hovendal, C.; Predersen, S. A. Aliment. Pharmacol. Ther. 1991, 5, 85-89.

257. Garty, M.; Hurwitz, A. Clin. Pharmacol. Ther. 1980, 28, 203207.

258. Hoffken, G.; Lode, H.; Wiley, R.; Glatzel, T. D.; Sievers, D. Rev. Infect. Dis. 1988, 10, 138-139.

259. Hurwitz, A.; Robinson, R. G.; Vats, T. S.; Whittier, F. C.; Herrin, W. F. Gastroenterology 1976, 71, 268-273.

260. Marano, A. R.; Caride, V. J .; Prokop, E. K.; Tronkale, F.J .; McCallum, R. W. Clin. Pharmacol. Ther. 1985, 37, 629-632.

261. Gugler, R.; Allgayer, H. Clin. Pharmacokinet. 1990, 18, 210219.

262. Boulay, K.; Blanloeil, Y.; Bourveau, M.; Geay, G.; Malinovsky, J. M. Br. J'. Anaesth. 1994, 73, 475-478.

263. Savarino, V.; Mela, G. S.; Zentilin, P.; Cutela, P.; Mele, M. R.; Vigneri, S.; Celle, G. Dig. Dis. Sci. 1994, 39, 161-168.

J S960085V 